\title{
Kalıcı, Sürekli ve İlgili: Yaşsız Yaşlılar \\ (Perennialler)
}

\section{Mert Ersözlül Mehmet Ali Aydemir ${ }^{2 \star}$}

\author{
Senex Yaşlanma Çalışmaları Derneği Üyesi' \\ Muş Alparslan Üniversitesi, Sosyoloji Bölümü² \\ E-Posta: mertersozluu@gmail.com¹ \\ E-Posta: mali.aydemir@alparslan.edu.tr²
}

Geliş Tarihi: 20 Nisan 2021; Kabul Tarihi: 15 Ağustos 2021

Doi: 10.24876/senex.2021.37

Künye: Ersözlü, M. ve Aydemir, M. A. (2021). Kalıcı, Sürekli ve İlgili: Yaşsız Yaşlılar (Perennialler). Senex: Yaşlıık Çalışmaları Dergisi, 5(1), 19-46.

(1) $0000-0003-1763-5355^{1}$

(1) 0000-0002-9237-23832

\section{Özet}

Bu araştırma, yaşsız yaşlı toplumsal tipinin arkasında yatan sosyal gerçekliği anlama çabası içindedir. Yaşsız yaşııların (perenniallerin) yaşam stratejilerini ortaya koymak ve bu yaşam stratejilerinin altında yatan sosyal gerçekliğin daha iyi bir şekilde anlaşıımasını sağlamak araştırmanın amacıdır. Bu amaç doğrultusunda araştırma nitel teknikler ile tanımlayıcı olarak hazırlanmıştır. Araştırma mekânı Antalya ili olarak belirlenmiştir. Çalışma grubu, Antalya ili merkez ilçelerinde yaşayan 60 yaşüstü 7 erkek 8 kadından oluşmaktadır. Katılımcılara kartopu örneklem tekniği ile ulaşılmış ve yarı yapılandırılmış soru formu aracılığıyla derinlemesine mülakat gerçekleştirilmiştir. Gerekli teknikler ve prosedürler uygulandıktan sonra görüşmeler edinilen bilgiler ve konularına göre temalara ayrılmış ve analiz edilmiştir. Araştırmanın kuramsal çerçevesini toplumsal tip kuramı, yaşlılığın kümülatif avantajlar ve dezavantajlar teorisi ve Pierre Bourdieu'nun habitus kavramı oluşturmaktır. Bu kuramlar yaşam seyri perspektifinden değerlendirilmiştir. Elde edilen bulgular yaşsız yaşlı toplumsal tipinin oluşmasında; yaşam boyu öğrenme, sosyal ilişkiler, bireylerin dijital yatkınlıkları ve yaşa yönelik algıların etkili olduğunu göstermektedir.

\author{
Anahtar Kelimeler: \\ Toplumsa Tip • Yaşlanma • Yaşam Seyri • Yaşsız Yaşlılar
}

\section{Permanent, Continuous and Interested: Ageless Older Adults}

\begin{abstract}
This research aims to understand the social reality behind the ageless older adult's social type by getting information about the aging processes of the ageless older adults. From this point forth, the main aim of the research is to reveal the life strategies of perennials and to understand the underlying reason of the social reality and life strategies. For this purpose, the population of the research has been determined as the province of Antalya. The sample consists of 7 men and 8 women who are over the age of 60 living in the cenral districts of Antalya. Within this scope, the in-depth interviews were with the participants through a semi-structured questionnaire. The theoretical framework of the research contains the theory of social type, the theory of cumulative advantages and disadvantages of aging and the concept of habitus of Pierre Bourdieu. These theories have been discussed in terms of life course perspective. The findings obtained in this research about the ageless older adult social type show lifelong learning, social relationships, digital predispositions of individuals and their attitude towards age to be effective.
\end{abstract}

\section{Keywords:}

Social Type • Ageing • Life Course • Ageless Older Adults 


\begin{abstract}
Pek bilindik bir hikâye değildir Kenji ve Margot'un hikayesi... Bir maraton koşusunda tanışan ve hayatlarını birleştiren bu iki ihtiyarın hikayesini anlamak için Margot'un Kenji'ye veda sözlerine kulak vermemiz yeterli olacaktır sanıyorum.

En son bir araya geldiğimizde ortak

140. Yaş günümüzü kutladık ve nişanımızı duyurduk diye söze başlıyor Margot ve şöyle devam ediyor: "ihtiyarların aşkı hem farklı hem aynı. Ken ile gençlerin yaptığı her şeyi yaptık. Âşık olduk, seyahat ettik, birlikte bir ev tasarladık, bahçeye bitkiler ektik, ben biyografimi yazdım. Bana 'tatıı' diye hitap ederdi... Birbirimize sürekli 'çok şanslıyız' derdik ve öyleydik. Yani aşk ihtiyarlar için bile şaşırtıcı derecede lütufkâr olabilir... (Modern Love, 2019. Bölüm 8)
\end{abstract}

\section{Giriş}

Modernleşme ile insanlara gençliğin ideal bir durum olaraksunulması, yaşıılığa dair olumsuz yargıların artmasına ve kimi zaman yaşlılığın bir şanssızlık olarak görülmesine neden olmuştur. Yaşlanma sürecinin yaşlı bireyde meydana getirdiği olumsuz durumların aksine, yaşlıların yaşlarından bağımsız olarak öğrenmeye, yeni şeyler denemeye ve hayatın güncelliğine ayak uydurmaya yöneldiklerini söylemek mümkündür. Çünkü yaşlılar yeterlilikleri, bilgi birikimleri, becerileri ve bunları günlük yaşamda kullanabilme yeteneklerini içeren potansiyelleri içlerinde barındırabilirler.

Yaşamın doğal bir evresi olan yaşlılık döneminde sergilenen bireysel tutumlar, belirli bir zaman ve kültürde gelişen davranışlar içinde oluşturulmaktadır. Bireyler büyürken kendilerine ait bir bakış açısı geliştirip, kendileri için önemli olan noktalara özen göstermeye başlarlar. Bu etmenler, onların yaşamlarının belirli dönemlerini algılama biçimlerini de etkileyebilmektedir. Yaşlılık dönemi buna örnek olarak verilebilir. O zaman aklımıza şu sorular gelir: Insan ne zaman yaşlanır? Yaşlılığı belirleyen şeyler nelerdir? Yaşlılığın sınırları nelerdir? (Arun, 2018; 9). Yaşılıık çok boyutlu bir kavramdır bu nedenle yaşlılığın başlangıcı için belli bir yaş sınırı belirlemek zordur ancak insanın yaşama biçimi bunu gözlemlememize imkân verebilir
(Yıldız, 2014). Yaşlanma ve yaşlılığa dair fikirler, betimlemeler, anlamlar ve deneyimler, koşullara, zamana ve kültüre göre değişiklik gösterebilir (Morgen\& Kunkel, 2016 aktaran Arun, 2018; 9). Demografik dönüşümlerle toplum dinamiklerinin farklılaşması, üretim ve tüketim biçimlerinin, sınıfsal olarak yaşılıarın aile içindeki rollerinin ve aynı zamanda hem yaşlı bireyin hem de toplumun yaşlı, yaşlılık, yaşlanma algılarının da değişmesine sebep olmuştur. Bu nedenle toplum içinde bütün yaşlıları bilge, sözü geçen, danışılan kişi olarak tanımlamak gibi; elinde baston, kambur, huysuz, düşkün, vb. şekillerde tanımlamak da doğru olmayacaktır. Yaşlı olarak adlandırdığımız sosyal kategori çok farklı özelliklere sahiptir ve bu özellikler dünyadaki dinamiklerin değişmesi ile daha da heterojenleşmektedir. Bu farklı yaşlı tipleri ve tipolojileri içerisinde yeni bir grubun oluşumunu görmekteyiz veya onlar bizim için yeni görünür olmaya başladılar. Bu grup, yaşsız ve ilgili yaşlılar olarak tanımlanan "perennialler"dir. Perennial yaşlıların en büyük özelliklerinden biri, çağa ve çağın gerekliliklerine ayak uydurmalarıdır. Biyolojik olarak yaş almaya devam eden yaşlılar, bu süreçte sosyal medya kullanıp, zevklerine göre giyinmekten çekinmiyorlar; hobilerinden geri kalmayıp, yeni şeyler öğrenmeye meraklılar ve meraklarını sanılanın aksine sadece geleneksel yöntemlerle değil internet üzerinden edindikleri bilgilerle gideriyorlar. $\mathrm{Bu}$ kişiler aslında yaşlanmayacaklarını düşünmüyorlar, yaşsız kalacaklarını düşünüyorlar. Yaşsız kalmanın anlamı, onlara göre aslında çağa ayak uydurmaktır. Toplumda yeni yeni büyümeye ve görünür hale gelmeye başlayan perenniallerde bilgi toplumunun metaforlarını görmek mümkündür. Perennialler (yaşsız yaşlılar) de bilgi ve hız toplumu içinde yaşadığının bilincinde olan, çağın gereklerinin farkında ve ait olduğu toplumun gereklerine ayak uydurma çabasındaki yaşlıları işaret etmektedir. Diğer bir özellikleri ise, hayatla ve dünya ile ilgili olmaları, ilgilerini sürekli 
olarak canlı tutmalarıdır. Yani; Perenniallerin gündelik yaşam deneyimlerini biyolojik yaşın belirlemediği bir yaşam tarzı ile ön plana çıktıkları söylenebilir. Kısacası perennialler (yaşsız yaşılıar) sürekli genç kalan insanlar değillerdir. Onlar, genç ya da orta yaşlı birinin hâkim olduğu bir toplumsal yaşama yaşlıların da en az onlar kadar hâkim olduğunun göstergesidir. Bu grup kendini toplumdan geri çekmenin aksine, dilediğince topluma dahil olma arayışındadır.

$\mathrm{Bu}$ çalışmanın ana amacı, perenniallerin (yaşsız yaşlılar) yaşam stratejilerini ortaya koymak ve yaşam stratejilerinin altında yatan sosyal gerçekliğin daha iyi bir şekilde anlaşılmasını sağlamaktır. Dünya nüfusu ile Türkiye'de de hızla artmaya başlayan yaşlı nüfus oranı ve Türkiye'de yaşlanma sürecinin dar bir perspektifle ele alınması bu konunun seçilmesindeki temel motivasyonlardır. Çünkü, ülkemiz yaşlılık ve yaşlanma literatüründe karşımıza çıkan kısıtlı bakış açısı, yaşlıığı kapasitenin azaldığı, hayat kalitesinin düştüğü ve bireysel tatminin azaldığı bir dönem olarak kurgulanmasına sebep olmaktadır (Tuncer, 2020). Tüm bu durumlar, sosyal bilimler alanında yaşlılık çalışmalarına farklı perspektiflerden bakma ihtiyacını doğurmaktadır. Çünkü yaşlılık olgusu, genç, yaşlı ayırmaksızın herkesin hayatını, sosyal ilişkilerini, ekonomiyi ve toplumu farklı şekillerde etkileyecektir (Duben, 2019). Bu çalışmada, yaşsız yaşlıların toplum içinde kimliklerini nasıl inşa ettikleri, içlerinde barındırdıkları kendine has özellikleri ve yaşsız yaşı kavramının yaşlı bireylerdeki karşılıklarının ne olduğu belirlenmeye çalışılacaktır. Buradan hareketle metin beş bölümden oluşmaktadır. İlk bölümde teorik arkaplanüzerindedurulmuştur. Ikincibölümde araştırmanın yöntemi ele alınmaktadır. Üçüncü bölüm ise araştırmanın saha kısmı ve detaylı çözümlemelerden oluşmaktadır. Yaşsız yaşlılara ait bilgiler, sahada elde edilen çıktılar harmanlanarak sunulmuştur. Daha sonrasında bu çıktılar kavramsal çerçevede yer alan kuram ve yaklaşımlar göz önünde tutularak tartışılmıştır. Son bölüm ise sonuç ve önerilerden oluşmaktadır.

\section{Arka Plan}

Yaşılık çalışmaları açısından toplumsal tipleştirmeler, yaşlı algısının olgunlaşmasına katkı sağlamaktadır. Bu durum toplumların tarihsel değişimlerini, yaşam tarzı farklılıklarını ve yaşlılık tipolojilerini anlamamıza yardımcı olacaktır (Kanbir, 2020). Yaşlıların bir arada bulunduğu ve sürekli zaman geçirdiği bir ortamı canlı ve anlamlı kılan, o mekandaki yaşlı toplumsal rolü içinde kendine yer edinen yaşlı tipleri veya tipolojileri çeşitli şekillerde görünümler kazanabilir. Toplumsal tipler sayesinde toplumda var olan farklı rollerin kavranması, özgün yaşam tarzlarının gün yüzüneçıkarılmasıgibidurumlarsağlanabildiği gibi, var olan sosyal yapının ya da bireyin içinde yaşadığı toplumu anlamlandırabilmesi ve kavrayabilmesi sağlanabilir. Yani toplumsal tipler denildiğinde aslında işaret edilen toplumun bütünüdür. Toplumu meydana getiren kurumlar, mekânlar, bölümler ve yapılar kendi aktörleriyle vardır ve anlamlıdır (Aydemir, 2016).

Sosyal bilimler alanında yapılan toplumsal tip çalışmalarına bakıldığında yaşı bireylerin yaşam tarzlarını mercek altına alan ve yaşlıığın toplumsal olarak nasıl tezahür ettiğini inceleyen çalışmaların oldukça kısıtlı olduğu görülmektedir. Günümüzde Türkiye literatürüne bakıldığında yaşlanma ve yaşlılık ile ilgili yazılmış üç tane toplumsal tip çalışmasına ulaşılabilmiştir. Bunlardan birincisi Canatan (2014) tarafından yazılan Eski Toprak toplumsal tipidir. Bu çalışmada Eski toprak, verimli toprak anlamında kullanılmıştır. Eski toprak olarak tipleştirilen yaşlılar ise modern hale gelmiş yaşam alanına iyi uyum dengesini bozmayan her konuda bilgili ve yaşlı insandır. İkinci toplumsal tip çalışması ise Yıldız (2014) tarafından yapılmıştır. Yazar bu çalışmasında Ömür Dediğin programına 
konu olan yaşlıları tipleştirmiştir. Bu yazıda bireylerin yaşlılık durumları, yaşlının hayata bakışı ve yaşlılık dönemi sorunlarını ön plana çıkarmaktadır. Yeni yaşlılık tanımlamalarından ziyade ağırlıklı olarak ölüm, yalnızlık, zorluk, bakım-sağlık, gibi konular çerçevesinde kayıpların ön planda olduğu ve yaşlılığı daha çok tıbbileştiren bir portre sunmaktadır. Üçüncü toplumsal tip çalışmasında ise Ok (2014) ihtiyar toplumsal tipini ele almaktadır. Yazar bu çalışmasında ihtiyarın kelime anlamı üzerine açıklamalar yapmış ve ağırlıklı olarak ölüm ve din temaları üzerinden bir tipleştirme çalışması yapmıştır. Arun (2018), yaşlanma tarihi ile ilgili temel bilgilere bakıldığında çalışmaların dünyanın belirli bölgelerinde ağırlıklı yapıldığı geri kalan bölgelerde ise neredeyse çalışmalara rastlanılmadığı bilinmekle birlikte yaşlanma tarihi ile ilgili bu temel bilgilerin çoğunlukla Kuzey Amerika ve Batı Avrupa'daki kaynaklardan edinildiğini ve ne yazık ki Osmanlı Imparatorluğu dahil olmak üzere, Asya, Afrika ve Güney Amerika'da yaşlanma ve yaşıılığın geçirdiği serüven hakkında kaynaklara ulaşılamadığını belirtmektedir. Kuzey Amerika ve Batı Avrupa'daki kaynaklarda yaşııı̆ın üç tip altında toplandığı görülmüştür (Achenbaum, 2013; aktaran Arun, 2018). Birinci kategoride yer alan yaşılır beyaz ya da gri saçları, fiziksel olarak zayıf bedenleri olan yüzleri kırışık ve ağzında dişleri olmayan kişilerdir. İkinci kategoride yaşlılık, gençlik durumu ile kıyaslanmıştır ve betimlemeler yapılırken toplumsal yaşam içindeki statü, deneneyim çeşitlikleri de hesaba katılmıştır. Yaşlı bireyin, zengin ve güçlü ise saygıda kusura uğramadığı fakat bunun tersi özelliklere sahip ise acınası halde ve zavallı görüldüğü, ötekileştirildiği ve çoğu zaman şiddete uğradığı belirtilmektedir. Üçüncü kategoride ise betimlemelerin toplumsal cinsiyet bağlamında yoğunlaştığı dikkat çekmektedir. Yaşlı kadınlar, erkeklere nazaran daha fazla onur kırıcı davranışa maruz kalmakta, toplumsal açıdan da daha fazla mahrumiyet ve kayıp yaşamaktadır. Bunun en temel nedeni olarak ise iktidarın çekicilik ve güzellik gibi özellikleri gençliğe atfetmesi, yaşlı bireylerin özellikle de yaşlı kadınların bu özellikleri kaybetmiş olarak görülmesidir (Arun, 2018).

$\mathrm{Bu}$ araştırma açısından kuramsal anlamda diğer önemli nokta yaşam seyri perspektifidir. Araştırma, yaşlılık ve yaşlanmaya yönelik olumsuz ön yargı ve anlamlardan bağımsız özgün bir yaşlı toplumsal tipinin var olabileceğini ve toplumsal dinamiklerle bağlantılı olarak kendini ortaya koyabileceğini gösterme gayesindedir. Bu noktada yaşlıları içinde bulundukları o an (yaş) ile sınırlamak, anlamaya ve açıklamaya çalışmak ayrımcı (ageist) algıların üretilmesine katkı sunmaya devam edecektir (Arun, 2018). Bu yanılgıya düşmemek için görüşme yapılan yaşlıların yaşam seyrine odaklanmak önemli bir yer tutmaktadır. Yaşam seyri perspektifi en basit şekliyle, bireyin yaşamı boyunca edindiği deneyimlerin (olumlu veya olumsuz) geç yaşam döneminde bireyin yaşamını etkilediğini savunur. Özellikle gerontoloji alanı için zengin bir perspektif olarak tanımlanan yaşam seyri perspektifi, toplumsal roller, yaşam dönemleri, yaş/ kuşak farklılıkları, deneyimlenen avantaj/ dezavantajlara odaklanır (Holman\& Walker, 2020). Bireyin yaşamının erken dönemlerinde seçimlerini etkileyen yollar, gelişen tarihsel olaylar, değişen yaşam koşulları, bireyin geçtiği kritik ve hassas dönemler yaşlanmayı doğrudan etkileyebilir (Stowe \& Cooney, 2015). Yaşam seyri perspektifi, yaşlanma deneyiminin sadece genetik yapı gibi fizyolojik sebeplere indirgenemeyeceğini, kişinin sosyo-demografik nitelikleri ile içinde büyüdüğü ve yaşamını sürdürdüğü sosyal ortamın yaşlanma deneyimini ciddi anlamda belirlediğini ortaya koymaktadır (Wright, 2020). Bu durum özellikle artan yaş ile yaşlılar arasında heterojenleşen yaşlanma deneyiminin sunduğu çeşitliliği ve bu çeşitliliğe neden olan toplumsal etmenleri anlayabilmek açısından önemlidir. Yaşam seyri perspektifi, yaşsız yaşlı toplumsal 
tipini oluşturan bireylerin, yaşamın farklı evrelerindeki durumunu, edindikleri farklı sosyal rolleri, ilişkilerini, onları benzer bir yaşamda buluşturan olay akışlarını gözleyebilmemize de imkân vermektedir.

Araştırmanın kuramsal arka planını oluşturan önemli noktalardan biri de Kümülatif avantajlar/dezavantajlar [KAD] teorisidir. Teori hem kuşak hem de yaşla ilgili bireysel ve sosyal-yapısal süreçleri analiz edebilmek için bireylerin yaşamı boyunca elde ettiği avantaj ve dezavantajların birikimden yola çıkan bir bakış açısı sunar. Kuramın ana kaynağını birikim oluşturur. Bu birikim biyolojik yaşlanma ile ilgilenen araştırmacılar için hücresel bir okuma imkânı sunarken, yaşlanmayı sosyal bilimler perspektifinden okuyan araştırmacılar için toplumsal bir okuma imkânı sağlar. Teoriye göre erken yaşlarda maruz kalınan yoksulluk, travma ya da çeşitli hastalıklar gibi dezavantaja sebep olan koşulların ilerleyen yaşlarda yeni risklerle karşılaşma ihtimalini arttırabileceği gibi, tam tersine yine erken yaşlarda sahip olunan avantajların bireyin karşılaşacağı yeni riskler karşısında daha dirençli olmasına hatta bu risklerle hiç karşılaşmamasına sebep olabilir (Wright, 2020). Kısaca KAD, bireylerin yaşamlarının çocukluk gibi yaşamlarının erken dönemlerinde maruz kaldıkları ve yaşamları boyunca biriken avantaj ve dezavantajların yaşamlarının ilerleyen evrelerinde önemli sonuçların oluşmasına sebep olduğunu belirtir (Ferraro \& Shippee, 2009). Köklerini yaşam seyri perspektifinden alan kuram, zamanın ilerlemesi ile biriken avantaj ve dezavantajların sistematik olarak bireyler arası farklılaşmaya sebep olabildiğini belirtir. Dannefer (2003) bu farklılaşmaya, yıllar geçtikçe bireyler arasında ekonomi, sağlık, statü gibi durumların birikiminin sebep olduğunu belirtir ve bu teori için iki terimin özel dikkat gerektirdiğinden bahseder. Bu terimler; bireyler arası farklılık ve sistematik eğilimdir. Sosyal gerontoloji araştırmaları açısından değerlendirecek olursak bireysel farklılıkların yaşlııkta çeşitlilik ve heterojenlik olarak karşımıza çıktığını görebiliriz. Teori yaş ile ilgili klişeleşmiş tanımlar, yargılar ve söylemlere karşı çeşitlilik ve heterojenlik argümanı ile bir alternatif oluşturmaktadır. Sistematik eğilim ise daha yapısal süreçlerle ilgilidir. Toplumsal değişim ve dönüşümlerin yaş ile ilgili kavramlar üzerinde düzenli bir etkisinin olup olmadığını sorgulamaktadır.

Bu teori yaşam seyri perspektifinden bazı yönleri ile ayrılmaktadır. Öncelikle yaşam seyri perspektifi bir teori değildir. Bundan ziyade bireylerin yaşlanma deneyimlerini ve farklı yaşlanma desenlerini gözlemlememize imkân sunan bir bakış açısıdır. KAD ise bir teoridir. Bu teori bireylerin yaşam seyrinde elde ettikleri deneyimlerin onların yaşamlarının ileriki evrelerinde olumlu veya olumsuz birikimler ve bu birikimlerin yaşlı bireylerin hayatlarını kolaylaştırdığını veya zorlu bir hala getirdiğini iddia eder. KAD teorisinin bu araştırmada kullanılmasının nedenlerinden biri yaşam seyri perspektifinin tamamlayıcısı olarak görülmesidir. İkinci neden ise deneyimlerden elde edilen birikimlerin, özellikle de olumlu birikimlerin sağladığı avantajların perennial toplumsal tipinin oluşmasında önemli bir yer tutmasıdır.

Teorik arka planın en önemli ayaklarından biri olan habitus, Bourdieu'nun sosyoloji literatürüne kazandırdığı kavramlardan biri olarak toplumsal aktörün yaşam alanında edindiği konumu anlamlandırmak üzere kullanılır. Bourdieu'nun sosyal uzam olarak da adlandırdığı yaşama alanında birey, kendi hayat deneyimini anlamlandırma adına bir çabanın içerisindedir. Bu zaman zaman bir savaşı andırır -Bourdieu, kumar masası örneğini de kullanır-, aktörler bu savaşı sahip olduğu sermaye türlerine göre kazanmak adına stratejiler geliştirirler. Bu toplumsal aktörler, ihtiyaç duyulan sermayenin türüne göre sermayeler arası değişimler gerçekleştirir ve tedavüle sokarlar. Ekonomik, kültürel, sosyal ve sembolik sermaye türleri 
üzerinden genel bir tasnifle ayırdı̆̆ı bu donanımları edinme süreci ile aktör kendi deneyimini anlamlı bir çerçeve içinde meşrulaştırırken, yeni stratejilerle de hayatta kalma savaşı sürdürür. Habitus tam da bu süreğen hayatın içinde kendi yaşam alanını anlamlı hale getiren bireyin dünyasına işaret eder. İçinde olduğu ve içselleştirdiği hayat akışında ortaya çıkış biçimleri, görünümleri, dışa vurum şekilleri ile aktör kendi habitusuna uygun davranış kodlarını yansıtır. Insanların belirli kültürler içerisinde yaşaması sonucu, onların yaşam tarzlarından, yaptıkları seçimlere kadar kendini bir şekilde dışa vuran bir mekanizmadır. En temelde dışsal toplumsal yapıların içselleştirilmesiyle ortaya çıkan ve faillerin eylemlerini organize eden bir ilkedir (Palabıyık, 2011). Bireyin bedenindeki eyleme dökülmeye hazır yatkınlıklar bütünü olan habitus, çok geniş bir kapsam içerisinde, gündelik hayattan siyasete, kültürel beğenilerden konuşma tarzına kadar her durumda insanın toplumsal eylemlerinin kaynağıdır. Bu araştırmada habitus, araştırmanın kavramsal çerçevesini oluşturan KAD teorisi ve yaşam seyri perspektifinin açıklamada eksik kaldığı yerlerde tamamlayıcı olmaktadır. KAD ve yaşam seyri perspektifi yaşlanma sürecinde yapısal ve bireysel etkileri anlamamızı sağlamaktadır. Toplumsal tipi analiz edebilmek için KAD ile yaşam seyrine bakmak gerekmektedir. Ancak yaşam seyrindeki avantaj ve dezavantajların bedene nasıl yansıdığı, duyguların hayatı nasıl etkilediği, kişinin anlam dünyasını nasıl kurguladığı ve sahip olduğu potansiyelleri veya bariyerleri kültürel ortama nasıl taşıdığı gibi konuları anlamak için işlevsel değillerdir. Yaşlanma ile bahse konu başlıklarda ortaya çıkan değişim, görünüm, yapılanmaları anlamada habitus teorisi kullanılacaktır. Zira perennial bireyin yaşam akışında ortaya çıkan bu yeni halin içeriği, onu var eden toplumsal koşullarda, onun tercih ettiği ve dolayısıyla anlamlandırdığı yaşam alışkanlıklarında, geçmişten bugüne taşıdığı birikimlerinde, zaman içinde bedeninde ve dış görünümünde kendini gösteren işaretlerde açık veya gizli bir şekilde yer almaktadır. Perennial bireyin bu yeni durumu anlamlı hale getirme çabası ile yeni bir sosyalleşmeyi deneyimlediği yani aslına bakılırsa dahil olduğu habitusu ileriki yaşlarda, yaşam kalitesini arttıracak şekilde geliştirdiği iddia edilebilir. Tüm bu eksenlerde konuyu çerçevelendirmek için habitus teorisi sahadan devşirilen bilgiyi değerlendirme imkânı sunacaktır. Böylece yaşlıların içerisindeki yaşsı yaşlı toplumsal tipinin hem avantajlı toplumsal konumları anlaşılacak hem de bu avantaj/ dezavantajların bedendeki görünümleri de dahil olmak üzere pek çok farklı açıdan analiz edilebilecektir. Genel itibariyle perennial bireylerin günlük yaşam akışını, pandemi gibi olağanüstü zamanlarda kendilerini hangi duyguların sarmaladığını, kendilerine dönük ve kendilerinin dünyaya ilişkin algılarını, duygu ve beden arasındaki analojiyi kurmanın imkanını vb. konuları anlamanın yolu habitus kavramının sağlayacağı projeksiyon ile mümkün olacaktır.

\section{Yöntem}

$\mathrm{Bu}$ araştırma tüm bu durumlar göz ardı edilmeden nitel teknikler kullanılarak tanımlayıcı olarak hazırlanmıştır. Nitel araştırmanın evreni temsil etmek gibibir amacı yoktur. Çalışmada ası önemli olan konunun hiç değinilmemiş noktasını yakalamak yani konuyu derinlemesine araştırmaktır. Doğası gereği anlamlar dünyasına değinen ve nasıl sorusunu farklı yaklaşımlarla irdeleyen bir araştırmadır. Bu araştırmada temel hedef perennial (yaşsız yaşlı) kavramının yaşlılarda bulduğu karşııkları belirlemek olup buna uygun olarak nitel bir araştırmanın tasarlanmasıdır. Tartışılanlar ışığında perenniallerin (yaşsız yaşlılar) yaşam stillerinin daha iyi anlaşılması ve yaşsız yaşlıların bu tip bir yaşam tarzını seçmelerinin altında yatan sosyal gerçeklik anlaşılmaya çalışılacaktır.

Araştırmanın örneklemini Antalya ili 
oluşturmaktadır. Antalya ili; iklimi, doğal güzellikleri ve sağladığı olanaklar bakımından özellikle emeklilik döneminin geçirebileceği bir il konumunda olması sebebiyle yaşlılar tarafından tercih edilmektedir. Yerel yönetimlerin yaşlılar için sunduğu imkanlar da göz önünde bulundurularak, perennial (yaşsız yaşlı) toplumsal tipini daha iyi anlayabilmek açısından Antalya ili Merkez ilçelerinde (Muratpaşa, Kepez, Konyaaltı) yaşayan 60 yaş ve üzeri bireylerle görüşülmesi planlanmıştır. Araştırmada saha süreci ilk olarak pilot çalışmayla başlamıştır. Gerçekleştirilen pilot çalışmada Antalya ili Muratpaşa ilçesinde yaşayan 3 kadın ve 2 erkek katılımcı ile yarı yapılandırılmış soru formu aracılığı ile mülakat yapılmıştır. Yaşları 60- 75 aralığında değişmekte olan katılımcılara kartopu örneklemkullanılarakulaşılmıştır. Araştırmanın uygulanabilirliğini test etmek ve kalitesini sağlayabilmek açısından yapılan pilot çalışmada, katılımcılar ile yapılan görüşmeler sonucunda katılımcıların verdiği cevaplar yazıya dökülerek pilot çalışmanın analizi tamamlanmış ve sonuçlar hazırlanmıştır. Elde edilen sonuçlar toplumsal gerçeklik içinde var olan yaşsız yaşlı toplumsal tipinin ortaya konulması bağlamında daha farklı bakış açılarına duyulan ihtiyacı ortaya çıkarmıştır. Bu nedenle soru formu yeniden tasarlanmıştır. Pilot çalışma sonrasında 10 kadın 10 erkek olmak üzere toplamda 20 katılımcı ile görüşülmesi planlanmıştır. Ancak görüşmeler sırasında sorulan sorulara retorik cevapların verilmeye başlanması ve araştırmanın sınırlılıkları nedeniyle 7 erkek, 8 kadın olmak üzere 15 kişi ile görüşme yapılmıştır. Mücbir bir sebep olarak değerlendirilen Covid-19 salgını ve beraberinde gelen pandemi süreci araştırmanın sınırlıığını oluşturmaktadır. Hastalığın en çok etkilediği gruplardan biri olarak düşünülen 65 yaş ve üzerindeki bireylere yönelik uygulanan kısıtlamalar ve onların bu süreçte sosyalleşebileceği mekanların kapalı olması araştırmada hedeflenen kitleye ulaşmada zorluklara sebep olmuştur. Katılımcılara kartopu
Örneklem tekniği kullanılarak ulaşılmıştır. Kartopu örneklemde başlangıçta çalışıımak istenen birkaç olay araştırmacıyı tıpkı küçük bir kartopunun büyümesi gibi tahmininden daha çok katııımcıya ulaşmasını sağlayabilir (Özen\& Gül, 2007). Bu nedenle bu örneklem tekniği uygun görülmüştür ve katılımcılara ulaşmak için tercih edilmiştir. Yaşsız yaşılıarın sosyal medya ve internet gibi mecraların aktif kullanıcısı oldukları düşüncesinden hareketle, görüşmelerin bir bölümü internet ortamında görüntülü (video) olarak bir bölümü ise yüz yüze gerçekleştirilmiştir. Görüntülü olarak gerçekleştirilen görüşmeler aynı zamanda araştırmanın sınırlılıklarını aşma stratejilerinden birini de oluşturmuştur.

Araştırma, alan araştırmalarından mülakat tekniği kullanılarak gerçekleştirilmiştir. Yarı yapılandırılmış soru formu hazırlanıp ana başlıklar belirlenip bu çerçevede sorular sorulmuştur. Görüşmenin seyrine göre zaman zaman yeni sorular eklenerek görüşmelerin derinleşmesi sağlanmaya çalışılmıştır.

Araştırma boyunca en çok dikkat edilen noktalardan biri de etik boyuttur. Etik olarak bir hataya düşmemek için saha süresince birkaç yol izlenmiştir. Bunlardan birincisi gönüllülük ilkesidir. Katılımcılar araştırmaya tamamen gönüllük ilkesine bağlı olarak dahil olmuşlardır. Mülakatlara başlanmadan önce katılımcılara, yapılan araştırma hakkında bilgilendirme yapılmıştır. Daha sonra aydınlatılmış onam metni okunarak sözlü bir şekilde rızaları alındıktan sonra görüşmelere başlanmıştır. İkincisi ise etik kurul onayıdır. Yüz yüze gerçekleştirilen görüşmelerin bir bölümü resmî kurumlarda yapılmıştır. Bu nedenle etik kurul raporu alınmıştır

\section{Hayata Daimî Tutunanların Portresi}

Bu bölümde yaşsız yaşlı toplumsal tipini oluşturan bireylerin ilk bakışta nasıl tezahür edildiğine dair zihinde bir izlenim sunabilmek için bireylerin sosyo-demografikbilgilerinden, 
popülerkültürel taleplerine, sanatsalilgilerine, katılım sağladıkları etkinliklerine, hobilerine, entelektüel ilgilerine ve boş zamanlarını nasıl değerlendirdiklerine odaklanılmıştır. Görüşmecilerden elde edilen yanıtlar, yaşsız yaşlı tipinin toplumsal görünümlerinin ortaya çıkarılmasını sağlayacaktır. Çözümlemeler yapılırken, katılımcıları deşifre etmemek adına her katılımcıya bir kod verilmiştir. Katılımcıların sosyo-demografik özellikleri Tablo.1' de gösterilmiştir. Yanıtlarda kullanılan kodlar cinsiyete göre belirlenmiş, K (Kadın) ve E (Erkek) olarak tasnif edilmiştir. Katılımcıların tamamı emeklidir ve emekli gelirine sahiptir. Görüşmecilere ayrıca ekonomik gelirlerine ilişkin bir soru yöneltilmemiş, sınıfsal konumlarına ilişkin kendi değerlendirmelerini yapmaları istenilmiştir. $\mathrm{Bu}$ itibarla görüşmeciler kendi görüşleri doğrultusunda orta-orta üst ve üst sınıfsal konumda olduklarını beyan etmişlerdir. aile üyeleriyle birlikte yaşayan 3 kişi yer almıştır. Görüşmelerden elde edilen bilgiler ışığında hane içi insan sayısı ve çeşitliliği ile kişinin hane dışındaki sosyal dünyası arasında bir etkileşim olduğu belirlenmiştir. Nitekim hane içinden hane dışına sarkan bir etki düzeyi görülmüştür. Bekâr, dul veya boşanmış görüşmecilerin kendilerine ilişkin verdikleri bilgilerde görüldüğü kadarıyla arkadaşlarıyla vakit geçirme, sosyal medyada etkileşim kurma, geziye çıkma ve kendini daha özgür hissettiği ev dışı etkinliklere katılma tercihleri vurgulanmıştır. Buna karşın, hane içi insan sayısı ve çeşitliliği yüksek olan görüşmecilerin sosyal hayatında ise aile üyelerinin etkileri tespit edilmiştir.

Katılımcıların ifadelerine göre oluşturulan temalarda görüşler sistematik bir şekilde analize tabi tutulmuştur. Görüşmecilerin ifadelerinden yola çıkılarak hazırlanan

Tablo.1: Katılımciların Profili

\begin{tabular}{|l|l|l|l|l|}
\hline Kat1lımcılar & Yaş & Ĕgitim & Sinıfsal Görüş & Medeni Durum \\
\hline K1 KADIN & 67 & Üniversite & Orta Üst & Dul \\
\hline K2 KADIN & 65 & Üniversite & Orta Üst & Bekar \\
\hline K3 KADIN & 60 & Lise & Orta & Evli \\
\hline K4 KADIN & 64 & Lise & Orta Üst & Evli \\
\hline K5 KADIN & 72 & Lise & Orta Üst & Dul \\
\hline K6 KADIN & 75 & İlkokul & Orta & Evli \\
\hline K7 KADIN & 91 & Üniversite & Üst & Bekar (Boşanmış) \\
\hline K8 KADIN & 67 & Lise & Orta Üst & Bekar (Boşanmış) \\
\hline E1 ERKEK & 60 & Üniversite & Üst & Bekar (Boşanmış) \\
\hline E2 ERKEK & 61 & Üniversite & Üst & Evli \\
\hline E3 ERKEK & 66 & İlkokul & Orta & Bekar (Boşanmış) \\
\hline E4 ERKEK & 70 & Y.Lisans & Orta Üst & Evli \\
\hline E5 ERKEK & 64 & Üniversite & Orta & Evli \\
\hline E6 ERKEK & 65 & Yüksek Okul & Orta Üst & Evli \\
\hline E7 ERKEK & 62 & Lise & Orta & Evli \\
\hline
\end{tabular}

Katılımcıların profilini oluşturan unsurlardan biri de bireylerin konutlarında yaşayan kişi sayısı ve birlikte yaşayan insanların çeşitliliğidir. Bireyin hanesinde kiminle yaşadığı onların yaşam tarzlarında belirleyici etkenlerden biridir. Araştırma kapsamında yapılan görüşmelerde yalnız yaşayan 5 kişi, eşiyle yaşayan 7 kişi, eşi, çocukları ve diğer temalarda üç ana boyut belirlenmiştir. Bunların ilki "Yaşam Boyu Öğrenme" olarak ifade edilmiştir. Bu tema etrafında görüşmecilerin kendilerini geliştirme amaçlı giriştikleri etkinlikler temel alınmış ve temanın içeriğinde yer alan başlıklara göre analizler gerçekleştirilmiştir. Bu anlamda ilk temanın içeriğine bakıldığında spiritüel çabalar, 
mesleki, sanatsal ve kültürel faaliyetlere katılım, gezi ve turistik faaliyetlerde yer alma, yenilikçi ve öğrenmeye açık etkinliklerde kendini gösterme vb. ön plana çıkmaktadır. Erkek ve kadın görüşmecilerin tamamı bu yönde faaliyetlere katılım sağlamak suretiyle kendi kişisel gelişimlerini bir yaşam boyu öğrenme faaliyetine çevirdiği görülmektedir. Perennial toplumsal tipinin dikkate değer bir özelliği olarak bu temanın önemi vurgulanmaktadır. Aktif bir özne olarak Perennial tipler kendini gösterme konusunda isteklidir, yaşlanma ile durağan ve yavaşladığı varsayılan akışın aksine daha hareketli ve verimli bir süreç içine girme çabaları dikkat çekmektedir.

Bir diğer temada ise "Dijital Yatkınlık" başlığı kullanılmıştır. Görüşmecilerin neredeyse bir diğer ortak özelliği ise hemen hepsinin dijital araçlara yönelik ilgilerinde görülmektedir. $\mathrm{Bu}$ ilgileri anlarken vurgulanması gereken kısım fizyolojik ihtiyaçlar ile sosyal ihtiyaçların birbirine karışmış olduğudur. Hemen her katılımcı için sosyal medya kullanmak ve yaşamı kolaylaştırmak amaçları birbirini tamamlayan ihtiyaç kalemleri haline gelmiştir. Gerek sosyal medya üzerinden geliştirilen arkadaşııklar ve sosyal etkileşimler, gerek gündemin takibi ve bilgilenme gerekse de uzak yerleşimlerdeki aile üyeleri ve yakınlarla ilişkide kalmanın bir yolu olarak dijital yatkınlık Perennial tiplerin ana özelliği olarak tezahür etmektedir. Bu başlığı tamamlayan bir diğer tema ise sosyal ilişkiler ağının anlaşılması amacını içermektedir. Hemen hemen tüm görüşmecilerin hayat görüşü ve insanlarla kurduğu ilişki düzeyinde bir pozitif bakışın, ilişki kurma ve sürdürme istediğinin olduğu görülmektedir. Hatta bu isteklerinin bir yansıması olarakgörüşmecilerinyeni mekânlar ve imkânlar arayışında olduğu görülmektedir. Bu anlamda "Tazelenme Üniversitesi" olarak ifade edilen yaşlılara dönük çabanın katılımcıların dünyasında önemli bir yere sahip olduğu görülmektedir. İkinci temayı destekler ve tamamlar mahiyetteki bir diğer tema ise "Sosyal iliş̧kiler" başlığı altında hazırlanmıştır. Bu tema altında görüşmecilerin sosyal ilişki ve etkileşim pratikleri gündeme getirilmiş ve kendilerini sosyal dünya içinde nasıl konumladıkları gösterilmiştir. Özellikle arkadaşlıklar, geniş aile ilişkileri, yeni tanışıklık ve sosyal çevre arayışları, evlat ve torun ilgileri gibi Perennial tiplerdeki sosyal yönelimler yeni bir toplumsallaşma arayışının göstergeleridir.

Oluşturulan temalarda son olarak yer verilen bölüm, yaşlılık ve yaşlılığın algılanışı üzerine odaklıdır. Bu başlık bir toplumsal tip oluşturma konusunda besleyici bilgilere erişilmesini sağlamıştır. Buna göre bireylerin kendilerini algılaması, yaşlılık ve yaşlanma gibi yaşam evrelerinin nasıl şekillendiği ve karşılık bulduğunu ifade etme anlamında önemli bilgiler içermektedir. Özellikle yaşlılık olgusu ile örtüşen bir durum olarak emeklilik halinin görüşmecilerde ne anlam ifade ettiği soruşturulmuştur.

Makalenin bundan sonraki kısmında bahse konu temalar etrafında elde edilen bilgilerin sistematik ve dayanakları ile sunulması sağlanacaktır. Hemen her bir temanın bir başlık etrafında tartışılması ve sunulmasına çalışıldı.

\section{Bir Yaşlanma Serüveni Olarak Yaşam Boyu Öğrenme}

Görüşme yapılan bireylerin hemen hemen hepsinin öğrenmeye, öğretmeye ve keşfetmeye olan ilgileri, sorulara verdikleri cevaplardan anlaşılabilmektedir. Bu faaliyetler farklı biçimlerde gerçekleşmektedir. Bazı katılımcılar mesleki açıdan kendilerini geliştirmeye odaklanırken; bazı katılımcıların kişisel ilgi ve yetenekleri doğrultusunda yeni şeyler öğrenmeye başladığı görülmektedir. Bu öğrenme faaliyetleri kültür sanat alanında olabildiği gibi, yeni bir yabancı dil, yeni bir spor aktivitesi veya yeni yerler keşfetme şeklinde olabilmektedir. Bu uğraşlardan 
bazıları şunlardır: Müzik dersleri, resim, tamir işleri, kişisel gelişim, spritüal çalışmalar, felsefe, çeşitli türde yazılar, İngilizce, Arapça öğrenme ve sportif faaliyetler. Yapılan görüşmelerde, katılımcıların yeni uğraşlar edinmeye başlamalarının veya halihazırda yapmakta oldukları uğraşları geliştirmelerinin altında yatan bazı motivasyonlar görmekteyiz. $\mathrm{Bu}$ motivasyonlar, kişisel ilgi, yeni bilgiler öğrenme ve kendini geliştirme, sosyalleşme, depresyon ve zor durumlarla başa çıkma stratejileri olarak sıralanabilir. Katılımcıların verdiği cevaplar ise şu şekildedir:

2007'den 2019'a kadar kendi özel ilgi alanlarımda araştırma yapmak için kendime zaman ayırdım. Bunlar bilim, felsefe ve spritüal çalışmaları kapsar nitelikteydi. Daha sonra ise tamamen spritüal çalışmalar oryantasyonlu olmaya başladı (E1, 60 Üniversite).

E1 yaşam boyu öğrenme faaliyetlerine diğer katılımcılardan farklı olarak bilim ve felsefe ile ilgili okumalar, araştırmalar yaparak ve spritüel çalışmalar yaparak devam etmektedir. Buna karşın K2 katılımcısı gezmeyi ve yeni yerler keşfetmeyi çok sevdiğini belirtmiştir. Yaşam boyu öğrenme faaliyetlerine bu yönde devam etmektedir.

"...yaşamım boyunca bir şeyler öğrenmek ve her daim bir şeyler öğrenmek çabası içindeyim. Özel bir çaba değil. Bunu hobim yaptım diyelim. Böyle bir yaşam tarzım var ve bundan da mutluyum. Bu arada seyahat etmeyi seviyorum. Yurt içi ve yurt dışı seyahatler yapıyorum. Hatta bir gün bir bayan arkadaşımla sırt çantalarımızı aldık Tayland malyand gezmeye gittik. Bundan iki üç yıl önce düşün şimdi 65 yaşındayım demek ki 63 yaşımda sırt çantalı bir seyahate çıkma cesareti de gösterdim kendimde (K2, 65 Üniversite).

E1 ve ${ }^{\prime} 2^{\prime}$ nin ifadelerinden hareketle kişisel ilgi ve meraklarının kendilerini yönlendiren bir faktör olduğunu görmekteyiz. K1' in ise uğraş ve entelektüel ilgilerine, yaşadığı kayıplardan sonra yoğunlaştığı görülmektedir.

Eşimin ölümünden sonra 2,5 yıl kadar bir travma yaşadım. Psikolojik destek aldım. Sağlık sorunlarım oldu, yanlış teşhis koydular kansersin dediler... intihara teşebbüsüm oldu... Ama bunlar engel olmadı benim için. Yaşlı evine geldikten sonra Latin dans yarışmalarına katıldık bu yarışmalara katılmak 2 aylık mesele değil. Temmuz- ağustos ayında Antalya'nın o sıcağında günde 7 saat çalıştığımızı bilirim ben bu yaşta. Bu yarışmalardan aldığımız ödüllerle, ben hayatımda bugüne kadar ödül almamıştım... Bunun dışında 14 tane daha kursa katılmıştım Rusça, ingilizce, bilgisayar, fotoğrafçılık... ondan sonra da NLP kişisel gelişim kursları. Hepsi bitti hepsini başardım. Şimdi de Akdeniz Üniversitesi Tazelenme Üniversitesi 4. Sınıf öğrencisiyim (K1, 67 Üniversite).

K1' e baktığımızda uğraşlarının, hobilerinin ve yeni bir şeyler öğrenme çabasının ortak bir amacı olduğunu söylemek mümkündür. Bu katılımcının zorlayıcı süreçleri pozitif bir duruma çevirmek için hayata aktif olarak katılmaya devam ettiğini görmekteyiz. Bu noktada, tüm katılımcıların yaşam boyu öğrenme ile ilgili ifadelerine genel olarak bakıldığında; kişisel ilgi ve meraklarının peşinden giden, kültür ve sanata ilgili, yeni şeyler öğrenmeye meraklı, sağlığına özen gösteren ve en önemlisi kendisine zorluklar ve kayıplarla başa çıkma stratejileri geliştirebilen bir yaşlı tipi ile karşılaştığımızı görmekteyiz.

Genel kanı olarak yaşlı bireylerin yıllardır devam ettirdikleri hayat akışlarının emeklilik gibi keskin bir viraj ile aşılması sonrasında bir boşluğa düştüğü ve eskisinden daha durağan bir evreyi tecrübe zorluğu ile karşılaştığı düşünülmektedir. Bu durum yeni bir sosyalleşme evresi olarak yaşlılar için aşılması gereken bir motivasyon da üretmektedir. Bunu sağlayan sosyal çevrenin potansiyel imkanları ve içsel gerilimin 
bastırılma çabası örtüştüğünde yaşlılık aktif bir süreç olarak karşımıza çıkmaktadır. Görüşmelerimizde sıklıkla görülen, yaşlıların kurslarla, yeni beceriler edinme çabalarıla, farklı öğrenme programlarıyla, dans, müzik, dil gruplarında yer almalarıyla hayatın olağan akışına karşı güçlü bir duruş ve pozisyon aldıkları anlaşılmaktadır. Bu durum yaşam boyu öğrenme olarak ifade edilen yenidünya tecrübesini örneklemektedir. Öğrenmenin sonsuz, sürekli ve yeni durumlara uyarlanabilir içeriğe sahip olması özellikle yaşlı bireyler için daha da önem taşımaktadır. Seyahat, sanat, beceri özellikle ön plana çıkan süreklilik arayışının önemli parçaları olarak görülmektedir.

\section{Günlük Yaşam Akışında Yaşsız Yaşılıarı Anlamak}

Yaşsız yaşlıların hayat alanını anlamak onların gündelik ritüellerini kavramayı gerektiriyor. Yaşamdan geri çekilmenin aksine teknoloji ve interneti hayat alanının olağan parçası haline getiren yaşsız yaşılıar, gündelik hayat akışının organizasyonunu da yine bu araçlar etrafında tanımlıyorlar. Bu anlamda yaşsız yaşlıların gündelik hayat akışında dijital araçlara olan ilgi ve yatkınlığın yeri önemlidir. Dijital araçların yaşsız yaşlıların gündelik hayat organizasyonunu ve sosyal etkileşimlerini planlama, belirleme ve sürdürme anlamında önemli olduğu görülmektedir. Yaşsızyaşlıların dijital yatkınlıklarını anlamak ve sosyal medya gibi online platformların hayatlarındaki yerini öğrenmek için doğrudan bu minvalde bir soru sorulmuştur. Kendilerine yöneltilen bir soruda özellikle internet ve sosyal medya ile olan ilişkileriyle bu mecraları hangi amaçlarla ve ne düzeyde kullandıkları tespit edilmiştir.

internetle aram mükemmel. Ben Isparta' da görev yaptım mesela. Illk ADSL internet Isparta'ya geldiğinde 250 kişiye gelmişti. ilk alanlardan biri de benim... Ben çok meraklıyımdır, internet olsun bilgisayar olsun hatta zamanında birtakım programlarda yazdım. Hala internette dolaşır ve hala kullanan muhasebeci arkadaşlarımız var... Internet ve sosyal medya benim için vazgeçilmez bir olay. Hiç bankaya gitmem para yatırmam para çekmem. Her şeyi cep telefonumdan hallederim. Sosyal medya mecralarını da rahatça kullanabiliyorum hiç sıkıntı yok (E5, 64 Üniversite).

Katılımcının internetin ülkemize geldiği yıllardan beri kullanmasının onun dijital mecralara yatkın bir birey olmasına yardımcı olduğunu ve hayatının vazgeçilmez bir parçası haline geldiğini görmekteyiz. Bir başka katılımcı ise online platformları kullanım amacı olarak gündelik işlemlerini kolaylaştırması ve faydası dolayısıyla tercih ettiğini belirtmiştir.

internet, sosyal medya vs. ihtiyaç olması halinde kullanıyorum. Ama bir süreklilik ya da bağımlıık ya da aşırı bir tarzda değil. Hayatımı işgal edecek tarzda değil. Gerektiği kadar işime yarayacak kadar. Çok faydalı buluyorum, hayatımı çok kolaylaştırdığı zamanlar oldu oluyor. Sosyal medyayı da kullanıyorum ama onu da işlevsel olarak kullanıyorum. Günlük hayat işlemlerim için kullanıyorum. Mesela bankacılık, resmi işler, ödemeler, ilgilendiğim konularla ilgilenen insanların yazılarına videolarına ulaşmak için kullanıyorum. Tercüme yapmak için sözlük olarak kullanıyorum. Günlük hayat akışından haberdar olmak veya özel araştırmalar yapmak için de kullanıyorum. Ama eğlence amaçlı ya da vakit geçirmek için kullanmıyorum (E1, 60 Üniversite).

E1'in sosyal medya ve internet kullanım amacı doğrudan ihtiyaç olarak gördüğü anlaşılmaktadır. Gündelik işlerinin yerine getirilmesinde, ihtiyaçlarının giderilmesinde önemli bir araç olarak gördüğü anlaşılmaktadır. Banka ödemeleri veya resmi işlemler gibi ihtiyaçlarını bu mecra üzerinden karşılarken kendi ilgi alanlarına yönelik araştırmaları da yine bu mecralar 
üzerinden rahatlıkla gerçekleştirebildiğini belirtmektedir. Katılımcının internet ve sosyal medyayı daha çok günlük gelişmeleri takip etmek için kullandığı anlaşılmaktadır. Ayrıca günlük yaşamda ihtiyaç duyduğu enformasyonu bu mecralar üzerinden sağladığını belirtmektedir. Bu durum yaşsız yaşlı toplumsal tipinin belirgin bir diğer özelliği olarak anılabilir. Zira aktif birey olarak kendisine sunulan imkânlardan etkin bir şekilde yararlanma talebi ve bu imkânlara adapte olabilme becerisi ile kendini göstermektedir.

...sosyal medyada arkadaşlarımla çok güzel şeyler paylaşıyorum. Öyle başka insanlar gibi ona buna sataşmak değil, bilgi akışıdır benim için ve bütün her şeyimi bilgisayardan yapmaya yöneliktir. Banka işlerimi falan... ben gitmem zaten bankaya falan. Onları hallederim. Arkadaşlarımla iletişimimi oradan kurarım. Annemin işlerini de oradan yapıyorum... (K1, 67 Üniversite).

K1' e baktığımızda, sosyal medya ve interneti hem arkadaşlarıyla sosyal ilişkiler kurmak hem de resmi işlerini gerçekleştirebilmek için kullandığı görülmektedir.

Toplumda belli bir yaşı aşmış bireylere yönelik ön yargılar pek çok kez karşımıza çıkmaktadır. Bu ön yargılardan biri, yaşı bireylerin dijital yatkınlıklarının yeterince olmadığı ve bu sebeple çağın gerisinde kaldığı yönündedir. Fakat bu araştırmada yaşsız yaşlı olarak adlandırdığımız toplumsal tipi oluşturan bireylerin bu ön yargıların tersine dijital yatkınlıklarının gelişmiş olduğu hatta internet, akıllı telefon ve bilgisayar kullanımına oldukça yatkın oldukları görülmektedir. Görüşme yapılan katılımcıların sosyal medya ve internet kullanımına verdikleri cevaplara bakıldığında ifadelerin birbirine yakın anlamlar taşıdığı görülmektedir. Verilen yanıtlarda iki önemli nokta karşımıza çıkmaktadır. Bunlardan birincisi işlevsellik, ikincisi ise düzeyli kullanım çabasıdır. Bu işlevselliğin ise ihtiyaçlar ve sosyal ilişkiler ekseninde şekillendiği söylenebilir. Katılımcıların bu mecraları günlük ihtiyaçlarını karşılamak (banka işlemleri gibi), güncel gelişmelerden haberdar olma ve çevrelerindeki diğer insanlarla iletişim kurma, katılacakları etkinlikleri takip etme gibi işlevler için kullandıkları görülmüştür. Toplumsal cinsiyet bağlamında bakıldığında ise erkek ve kadın katılımcıların sosyal medya ve interneti kullanım amaçlarının bazı noktalarda birbirinden farklılaştığını görebilmekteyiz. Erkek katılımcılar kadın katılımcılardan farklı olarak bu mecraları geçmişte çalıştıkları işler veya meslekleriyle ilgili araştırmalar yapmak için kullanmaktadır. Kadınların ise erkeklerden farklı olarakilgi alanları ve hobileri ile ilgili araştırmaları daha çok yaptıkları görülmektedir. Ancak bireyler toplumsal cinsiyet fark etmeksizin gündem takibi, sosyalleşmek, günlük işlerini gerçekleştirmek ve iletişim kurmak için bu mecraları kullanabilmektedir. Katılımcıların beyan ettiği bilgilerden anlaşıldığı kadarıyla, aktif çalışma ve üretkenlik döneminden emekli olmakla birlikte hayatı devam ettirirken, geçmiş dönemden getirdikleri bilgi birikimlerini ve alışkanlıklarını özellikle teknoloji kullanımı ve yeni online hizmetlere erişim konusunda da aktive edebildikleri görülmektedir. Bu durum yaşsız yaşlanma konusunda emeklilik öncesi yaşam alışkanlıkları ve çalışma hayatının önemini ortaya koymaktadır. Katılımcılarda, Bourdieu'nun sermaye ve habitus kavramları ile ortaya koyduğu gerçekliği örnekleyen yaşam alışkanlıklarını görebilmekteyiz. Zira katılımcılar bilgi sermayelerini ve yaşam alışkanlıklarını aktif yaşlanma tecrübesi içine dahil ederek yeni bir yaşam döngüsünü, hayatlarını kolaylaştıracak ve yaşam kalitesini artıracak şekilde kullanmaktadırlar.

Bubölümde değerlendirilen bir diğerunsurda katılımcıların sosyal ilişkileridir. Katılımcılara, sosyal ilişkilerini ve bunun arkasında yatan sosyal gerçekliği anlamak adına öncelikle dahaçok kiminle vakit geçirmeyi tercih ettikleri sorulmuştur. Bu sorulara verilen yanıtlara 
bakıldığında bireylerin anlatımlarında dört vurgu ön plana çıkmaktadır. Bunlar medeni durum, yalnız yaşamak, ilişkilerde seçicilik ve pozitiflik ilkesidir. Bireylerin sosyal ilişkileri bu dört motivasyon etrafında şekillenmektedir. Görüşme yapılan bireylerin hemen hemen hepsi sosyal ilişkilerinde seçici olduklarını belirtmişlerdir. Özellikle kadın katılımcılardan K2 ve K4 ilişkilerinde kendilerine pozitif enerji veren insanlarla sosyal ilişki kurmayı tercih ettiklerini belirtmişlerdir. Aynı zamanda bireylerin sosyal ilişkileri ve günlük yaşam aktivitelerini geçirdiği mekanlar arasında da ilişki olduğunu söyleyebiliriz. Çünkü bireylerin günlerini geçirdikleri mekanlar onların sosyalleşmesi ve sosyal ilişkiler kurmasında etkili bir unsurdur. Zamanının büyük kısmını yaşlı evlerinde veya tazeleme üniversitesinde geçiren katılımcıların, bu mekanlarda yeni insanlarla tanıştıkları, farklı kuşaklarla iletişime geçtikleri ve yaptıkları aktivitelerle kişisel gelişimlerine katkıda bulunduklarını söyleyebiliriz. Bu açıdan baktığımızda K1, K2 ve E3 gibi yalnız yaşayan bireylerin ön plana çıktıkları görülmektedir. Katılımcıların böyle bir yaşam tarzını seçmelerinin altında yatan sebeplerden biri olarak, hanede tek olmaları yani bir partnerle birlikte yaşamamaları gösterilebilir. Bunun altında yatan sebep ise özgürlüklerine düşkün olmalarıdır. Yani, yalnız yaşayan perenniallerde ev dışı bir sosyallik arayışı ön plana çıkmaktadır. Buna karşın ailesi veya sadece eşi ile yaşayan E4 bireyi gibi katılımcıların ise daha çok ev içi yani aile ile sosyalleşmesi ön plana çıkmaktadır.

...geniş bir aile çevrem var. Geniş aile çevresi nedeniyle doğal olarak sosyal ilişkilerim bayağı geniştir. Ayrıca arkadaş ilişkilerim de var. Kısmen ticaretle ilgilendiğim için, kısmen siyasetle ilgilendiğim için hem ticaretten hem siyasetten arkadaş ilişkilerim de vardır. Hatta zaman zaman bu arkadaş ilişkilerimden dolayı kendime zaman ayıramadı̆̆ım da oluyor. Ama arkadaş ve ailenin daha doğrusu herkesin yeri farklıdır. Hayata bakış açısı ve felsefe olarak herkesle doğru ilişkiler kurmaya çalışırım (E2, 61 Üniversite).

Katılımcının bu soruya verdiği cevaptan çevresi ile dengeli bir ilişki kurmaya çalıştığı anlaşılmaktadır. Özellikle vurgusu yapılan hususlardan biri de bireylerin yaşlanma evresinde devam ettirdikleri alışkanlıklarının kendileriyle aynı dünya görüşünü ve yaşam tarzını devam ettirme çabası içinde koruyucu davrandıkları ve bu duruma uygun insanlarla etkileşim içine girdikleri anlaşılmaktadır.

Arkadaşlarımla hayata bakışım, güncel olaylara bakışım, günlük yaşam biçimim aynı. Çünkü o tür insanları seçtim. Yani bana uymayan, atıyorum spor yapmayan, ülkenin problemleri ilgilenmeyen vs. insanlar bana uygun değil. Birlikte etkinlikler yapabileceğim dertleşebileceğim insanlar benim çevremde (E2, 61 Üniversite).

E2'nin sosyal ilişkilerini kendisi ile benzer özellikleri taşıyan kişilerle kurduğu ve bu konuda seçici olduğu anlaşılmaktadır. E1 ise,

Daha çok arkadaşlar ile görüşmeyi tercih ediyorum. Aile bağlarım çok güçlü değil. Boş zamanım pek yok ama tercihen zaman ayırıp görüştüğüm insanlar oluyor (E1, 60 Üniversite).

Neden arkadaşlarıyla daha çok görüşmeyi tercih ettiği sorulduğunda ise,

Geçmişe dayalı samimiyet, karşııılı anlayış ve değer içerdiği için yeni insanlarla tanışma kapısı açık olmakla herkesin hayatında asıl zaman ayırdığı birlikte zaman geçirebileceği insanlar anlaşabildiği insanlar olur benim de öyle. Yeni insanlarla tanışmak için çaba sarf etmiyorum ama kapı kapalı değil. Yeni tanışacağım insanların arasından da iyi anlaşacağım samimiyet kurabileceğim birlikte zaman geçireceğim insanlar olabilir. Ama kendi ana konularımla ilgili, spritüal konularla ilgi duyan insanlara daha çok zaman 
ayırıyorum (E1, 60 Üniversite).

K4 ise bu durumu şu şekilde ifade etmektedir,

Ben şuradaki çöpçüyle de oturup sohbet edebilirim. Torunlarımla da sohbet ederim. Her yaş grubuyla anlaşabilirim. Ama tek erkeklerle aram serindir. Erkeklerle oturup şöyle bir sohbette etmem. Erkek öğretmen arkadaşlarımla şöyle oturup bir kahve içmişliğimde yoktur. Çünkü eşim çok kıskançtır ve rahatsız eder beni. Yeni insanlarla tanışırım arkadaş olurum. Yalnız yeni tanıştığım insanlara bir merhaba derim iki gözlemlerim biraz duygusalım ben baktım ki bana pozitif enerji veriyor o zaman samimi olurum. Mesela Didim' deki yazlıkta iki üç tane Ingiliz arkadaşım var. Onlarla yogaya gittim. Bayanlarla tabi erkekler yok. Sosyal ilişkiler kurabiliyorum ve seviyorum (K4, 64 Lise).

K4'ün cevaplarında E2 ve E1 gibi sosyal ilişkilerindeseçicidavrandıklarıgörülmektedir. Bu seçicilik daha çok pozitiflik yani olumluluk etrafında şekillenmektedir. Aynı zamanda seçimlerinde eşinin baskın karakterinin etkilerini görmekteyiz. Eşi K4'ün arkadaşlık ilişkilerinin yönelmesinde etkindir. K1'in verdiği yanıtlara baktığımız zaman kendisi 67 yaşında olan birey kendisinden 19 yaş büyük olan annesine de bakım vermektedir. Bu nedenle şu an annesiyle zaman geçirmeyi tercih ettiğini belirtiyor.

Şimdi annemi gezdirmeyi, özellikle göz operasyonu geçirdiği zamanlarda önce parka sonra yemeğe götürüp onu mutlu etmeye çalışıyordum. Dışardayken çok mutlu çünkü. Mesela küçük arkadaşlarım var 25-30 yaşlarında. Onlarla sohbet ederiz. Gezmeye, yemeğe gideriz. Kedilerimiziden köpeklerimizden konuşuruz. Pandemi öncesi ise hem okul çevrem (Tazelenme Ünv.) hem de buradan (Muratpaşa Bel. Yaşlı Evi) arkadaşlıklarım vardı görüştüğüm ve tabi annem vardı (K1, 67 Üniversite).
K2'nin ise bu durumu şu şekilde ifade ettiği görülmektedir:

Bana pozitif enerji verecek benim de onlardan bir şeyler öğreneceğim insanlar olsun istiyorum. Sohbet edip birbirimizi anlayabileceğimiz insanlar olsun istiyorum. Hayattaki olumlu olumsuz şeyleri paylaşmak içinde seni anlayan insanlar olsun istiyorsun. Ben herkese karşı açık olan bir insan değilim ama kapalı kutuda değilim. A-B-C-D gibi kategoriler düşünün. A kişisiyle her şeyi paylaşmam A kendisini benim kankam diye düşünür ama öyle bir şey yok. Ben onun kapasitesine göre onun bir şeyleri paylaşıyorum. $O$ yüzden de her kademeden her yaştan insanla ilişki kurabiliyorum (K2, 65 Üniversite).

Buna karşın E3 ise şu şekilde ifade etmektedir,

Yalnız yaşayan bir insanım ben. Benim değiminle savrulan yaprak gibiyim... arkadaş çevresinde ise erkek olmanın dezavantajları var. Kadınlarda avantaj olan şeyler erkekler için dezavantaj olabiliyor.10 daireli bir apartmanda oturuyorum. Erkek olduğum için kimse benim kapımı çalmaz ama kadınlarda bu durumun öyle olmadığını görüyorum... (E3, 66 ilkokul).

Katılımcı bu durumu aşmak için sürekli olarak yaşlı evlerindeki aktivitelere katılarak sosyal çevre oluşturduğunu belirtiyor. Yine E4'ün verdiği yanıtlara bakıldığında ise daha çok aile vurgusu ve aile ile geçirilen zaman ön plana çıkmaktadır.

Aile ile daha çok vakit geçiririm. Eşim var zaten sadece aileden. Oğlum İstanbul'da. Yeni insanlarla da tanışmayı severim. Ama evimin kapısı açık değildir. Gönlümün, aklımın kapısı açıktır. Geniş anlamda açığımdır yani (E4, 70 Y.Lisans).

Perennialleri görünür kılan ve belirli bir toplumsal tip etrafında temayüz etmesini 
sağlayan özellikleri tüketim ve yaşam tarzı konusundaki tercihleri denilebilir. Zira onları diğerlerinden ayıran vasıfları ile seçkin kültürel tüketim örüntülerinin merkezde yer aldığı yaşam alışkanlığına sahip oldukları görülmektedir. Sanatsal zevkleri, entelektüel merakları, spor ve sağlık konusundaki duyarlııkları, sosyal ağlar ve arkadaşlıklara atfettikleri önem ile kendilerini açıç̧a farklı kılmaktadırlar. Ancak bütün bunların yanı sıra üretilen bu yaşam tarzının bilinçli bir seçime dayanması ve elbette farklı sermaye potansiyellerinin kullanımı dolayısıyla ulaşılan bir sonuç olarak değerlendirmek daha doğru olacaktır. Zira sahip oldukları hayat tecrübesi içinde geliştirilen alışkanlık, duyarlıık ve yaşama tarzının belirli bir düzeyde korunması, devam ettirilmesi için çaba içinde olunması böylesi bir tipolojinin kendiliğinden ortaya çıkmadığını ispat etmektedir. Yaşamın bütünüyle anlamlı kılınması, çalışma odaklı hayat ile emeklilik sonrası hayat arasında bir bütünlük yahut köprü kurmayı gerektirmektedir. Bu anlamda Perennial tipler için bu bütünsellik yahut iki evre arasındaki köprü veya köprülerin başarılı bir şekilde organize edilmesi, simgesel anlamda bir ayrışmayı da yansıtmaktadır. Emeklilik öncesi önemli bir simge olarak çalışma veya üretkenlik, emeklilik sonrası tembellik veya tüketici kimlik gibi tezat unsurları barındırdığında kırılma derinleşmektedir. Buna karşın Perennial tipler için çalışma veya üretkenlik farklı form ve anlamlarda devam eden bir sembolizm olarak yaşsız bireyin dünyasındadır.

Perennial bireylerde kültürel tüketim pratiklerinin belki de en önemlisi yaşlılığı bir fırsat olarak görmek ve tükenmişlik sendromundan çıkmanın yolunun yeni şeyler öğrenme, eksik bırakılanın tamama erdirilmesi, ukde kalanın giderilmesi, gelişimi farklı boyutlara taşıma ve bunlar için yeni imkân ve fırsatları kullanma çabası olarak görülebilir. Zira yenilenme üniversitesi gibi kurumsal faaliyetlerde kendine yer bulan bireylerin yaşadıkları hayata anlam katma arayışının bitimsiz bir çabaya denk geldiği görülmektedir. Seyahat, gezi programları, yeni dil öğrenme, beceri kazanma, bilgi toplama, yeni insanlarla tanışma vb. perennial bireylerde karşılaşılan kültürel özelliklerin başında sayılabilir.

Bu bölümde değerlendirilen temalardan biri görüşmecilerin günlük yaşam aktiviteleridir. Günlükyaşam aktiviteleri ekseni diğer temalar olan yaşam boyu öğrenme, dijital yatkınlık ve sosyal ilişkiler temalarıyla doğrudan veya dolaylı olarak ilişkilidir. Katılımcıların günlük yaşam aktiviteleri hakkında verdikleri bilgilere bakılınca, kendi sınırları içine çekilmiş ve gün geçtikçe bu sınırları içinde kalan bireyler olmadığı anlaşılmaktadır. Aksine kendi sınırlarını aşma çabasında, kendilerine sunulan imkanlardan faydalanma konusunda arayışlar içinde olan, hayatla bağlarını yönetme konusunda istekli bireyler olarak görülmektedir. Toplumsal hayata aktif katılım sağlamak ve kendi özne değerinin bilincinde olmak şeklinde özetlenebilecek bir hususiyet yaşsız yaşlı tipini tanımlamaktadır.

\section{Yaşa Yönelik Algılar}

$\mathrm{Bu}$ araştırmada perennial bireylerin yaş ve yaşlılıkla ilgili insan hayatının dönemsel mecralarını nasıl algıladıkları gerek genel toplumsal bağlamı içinde gerekse kendi hayat akışları içinde nasıl anlamlandırdıkları sorgulanmaktadır. $\mathrm{Bu}$ bölümde ortaya çıkarmaya çalıştığımız toplumsal tip olarak perennial bireylerin en önemli vurgusu olan yaşsız olma halini anlamanın ve ona dair bir çerçeve çizmenin imkanını yakalamaya devam ediyoruz. Yaşlanma ve etrafındaki bazı kavramların görüşmecilerin dünyasındaki yerine ilişkin sorgulamalarla bir algısal durumu ve tutumu belirginleştirmek bu başlığın ana gayesi olacaktır. Böylece yaşlılık, yaşlanma, emeklilik vb. gibi başlıkları irdeleyen sorular yöneltilmiştir. Alınan cevaplara göre yaşlıığın toplumsal çerçeveleri ve bu çerçeve 
içinde kendilerini nasıl konumladıkları belirlenmiş ve tartışmanın tipoloji çıkarma çabasında kullanılmıştır. Özellikle kendilerini konumladıkları ve ayırdıkları hususları belirginleştirmek, üretilen tipolojinin sınırlarını çizmede ve anlamlandırmada oldukça önemli sonuçlar üretmiştir.

Dinamik bir yapıya sahip olan yaşlılık dönemi gibi yaşlılık algısı da kişiden kişiye, toplumdan topluma veya çağdan çağa değişiklik gösterebilmektedir. Bu araştırmada katılımcıların yaşlılığa yönelik düşünceleri ve söylemlerinden hareketle oluşturulan temalara bakıldığında, kendine mahsus dönem, farklılıklar dönemi, zamanında yapamadıklarını yapmak gibi olumlu tabirlerin yanında, fiziksel engeller, hafif unutkanlık, vücuttaki değişimler ve muhtaçlık gibi olumsuz çağrışımlarla da karşılaşılmıştır. Araştırmaya katılan bireylerin verdikleri yanıtlar yaşııık dönemine bakışları hakkında daha fazla bilgi vermektedir.

Yaşlıı̆̆ızamanında yapamadıklarımızı, yapmaya imkân bulamadığımız şeyleri yapma zamanı olarak görüyorum (K1, 67 Üniversite).

K1' in yaşlılığı bir fırsat dönemi olarak gördüğünü söyleyebiliriz. Katılımcı bu dönemi sevdiği ve yapmak istediği uğraşlara zaman ayırabildiği bir dönem olarak değerlendirmektedir. E4 ise bu dönemi şöyle ifade etmektedir:

Yaşlılık benim için pek bir şey ifade etmiyor. Fizyolojik olarak ağırlaştığımı hissediyorum. Gözlerim bozuk, dişlerimde problemler var ama ölümcül bir hastalığım yok bildiğim kadarıyla. Ağrım sızım yok. Belim eğri lakin her sabah denize giriyorum. Günün doğuşunu izliyorum. Tamirden tutun aklınıza ne gelirse kendi işimi görüyorum. içsel olarak ve mesleki olarak gençlerin benden daha iyi yapabildiği şeyler olduğunu zannetmiyorum. Zıplamak, atlamak fiziksel olarak belki değil ama kendimi rahat hissediyorum (E4, 70
Y.Lisans).

Katılımcı geçmişten bugüne değerlendirdiğinde bu dönemi yaşamının diğer dönemlerinden farklı olarak fiziksel gerilemelerin olduğunu belirtmektedir. Bunun dışında gençlik ve orta yaş döneminde edindiği mesleki faaliyetleri ve hobileri devam ettirebildiği için bu döneme pek anlam yüklemediği görülmektedir. Diğer bir katılımcı olan E1 ise, günlük yaşam akışında yaş vb. bir kategoriye bağlı olarak hareket etmediği için belli çizgiler ile çizilmiş bir yaşam döneminin kendisi için bir anlam ifade etmediğini şu sözlerle belirtmiştir.

Kendimi bir kategori içinde hissetmiyorum. Bir konfora ya da belli bir yaşın zevkleri ve tercihleri içerisinde hareket etmiyorum. Ne giyimimde ne ilişkilerimde ne yeme içmemde. Yaşımla ilgili bir kategori içerisinde hareket etmiyorum. Aklıma bile gelmiyor yaşlılık. Yani yaşlılık kavramının bende bir duygusal karşılığı yok. Bu bir düşünce tarzı ile alakalı (E1, 60 Üniversite).

K2 ve E7'nin ise yaşlılığı yaşılıar üzerinden tanımladığı görülmektedir. K2 arkadaş çevresinden yola çıkarak gözlemlerinden bahsetmektedir. E7 ise toplumda var olan genel yaşlı algısından yola çıkarak yaşlılığı tanımlamaktadır.

Yeni nesil yaşlılar ya da yaş alanlar diyelim bu şekilde. Falanca yıldızdan bahsediyorlar dünyada top olanlardan. Dans yapıyorlar bilmem ne biz aynısını yapıyoruz. Daha önceden yaptık. Zaten yapıyoruz onu. Acı olan Türkiye'de bu tip yaşlıları sayısının az olması. Ama artıyor artık. Daha doğrusu benim çevremde facebook arkadaşlarım olduğu için görüyorum onları mesela torunlarıyla fotoğraf koyuyorlar anneanneler babaanneler genç kız gibiler. Değil mi? Zaten spor giyinenle ve kokoşlar da var tabi (gülüyor). Ama o dengeyi iyi tutanlarda var. Yeni gelenler eski yaşlılardan daha farklı 
geliyorlar... (K2, 65 Üniversite).

Yaşlılık deyince, bence insanın kendini hissetmesi ile alakalı. Yaşlılık hissetmesi gibi bir şey. Mesela ben yaşlılık hissetmiyorum kendimde. Eskiden 50'li yaşlara çok yaşlı diyorlardı. Hatta bazı ülkelerde 40 yaşında yaşlılıktan ölümler oluyordu. Tabi hayat standartları değişti ve bu sayı uzadı. Şimdi 50'yi geçtik 60 hatta 65 yaş sonrası yaşlı oluyor. Tabi yaşlanmak güzel bir şey. Tekrar genç olamaz insanoğlu ama yaşlılığı kendine göre daha iyi hissederek yaşarsa yaşlanması da daha iyi olur. Bence bunda dini inancın çok büyük etkisi var. Ben sesimde güzel olduğu için sureler okuyorum ve kendimi çok iyi hissettiriyor (E7, 62 Lise).

K7 ise yaşlılık hissetmediğini ve yaşlılığı yine fiziksel olarak hareketli olma durumu ile açıklamıştır. Ancak diğer görüşmecilerden farklı olarak yardımsever bir insan olmasının kendisini ayakta tutan şey olduğu anlaşılmaktadır.

Yaşlılık kişiden kişiye değişebiliyor. Ben yaşlılığı kabul etmiyorum. Ben hareketli bir insanım. Kafamda bir şey varsa onu canlandırmaya çalışıyorum. Birinin yardıma ihtiyacı varsa koşup onlara yardımcı olmaya çalışıyorum (K7, 91 Üniversite).

Katılımcıların yaşıııkla ilgili ifadelerinden yola çıkarak perennial bireylerin yaşlılık dönemin fiziksel gerilemeler dışında bir gelişim dönemi olarak gördükleri ve yaşamlarının diğer dönemlerinden ayrı bir dönem olarak değerlendirmedikleri görülmektedir. Bu durumdan dolayı perennial bireyler yaşlılık hissi taşımamaktadırlar. Bu dönemi yaşamdan geri çekilme dönemi veya kayıplar dönemi olarak algılamak yerine alternatif bir yaşam dönemi olarak tanımladıkları söylenebilir.

Katılımcıların yaşlanma ile ilgili sorulara verdikleri yanıtlardan oluşturulan temalara bakıldığında ise "birikim, süreklilik, geçmişten bugüne bütünlük, özgün hayat tecrübesi, sayısal bir rakam" gibi ifadelerin ön plana çıktığı görülmektedir. Bu ifadeler bireylerin yaşlanma algıları hakkında bize kuş bakışı bilgi vermektedir. Katılımcıların verdikleri yanıtlara detaylı olarak bakıldığında ise öncelikle K2,

Yaşalmak sayısal bir rakam. Yanisayısal bir şey. 3-4-5 gibi bir şey. Tabii ki yaş alırken de fiziksel bir takım yer çekim kuvvetinin de verdiği bir şey ile yüzde sarkmalar falan bunun yanında biyolojik olarak da birtakım eksilmeler aksaklıklar olabiliyor tabi. Ama yaş almak. Yaşlılık anlamında değil. Yaşlılık ne demek bilmiyorum. Yaş almayı biliyorum. Eskiden ben 30 olduğumda bile yaşımı zor söylüyordum. Ama şimdi rahatlıkla 65 yaşındayım diyebiliyorum. Çünkü daha özgüvenliyim. Çünkü bir yerde 65 yaşındayım deyince ve hiç göstermiyorsunuz dediklerinde hoşuma gidiyor (gülüyor) (K2, 65 Üniversite).

K2'nin yaşlanma sürecinde fiziksel değişimlere vurgu yaptığını görebilmekteyiz. Fiziksel olarak akranlarına göre daha dinç durumda olmasının ona hayatının daha erken evrelerinde olduğundan daha fazla özgüven sağladığını belirtmektedir. Bireyler yaşamlarının ilerleyen evrelerinde, yaşamın daha erken evrelerinde yaşamalarına imkân olmayan heyecan verici deneyimler yaşayabilirler. E5'in bu bireylerden biri olduğu söylenebilir. Katılımcının, yaşlanma sürecini yeni yaşam deneyimlerinden yola çıkarak değerlendirdiği görülmektedir.

Benim 30 yaşındayken torunum yoktu şimdi var onları seviyorum mesela. Işte 30'lu yaşlarda olaylara bakış açınız farklı şimdi çok daha farklı objektif çok daha farklı. Belli bir yaştan sonra insanların terazileri çok hassaslaşır. Kişileri konuşmasından bakışından tartabilirsiniz anlayabilirsiniz çünkü gerçekten hassaslaşıyor teraziniz. Karşınızdaki kişiyle ne yapacaksınız dostlukmu kuracaksınız çok rahat karar verebiliyorsunuz. Telefondan bile insanların insani duyularını 
hissedebiliyorsunuz çünkü hisleriniz de çok hassaslaşıyor (E5, 64 Üniversite).

Birey yaşlanma sürecinde hayatının erken döneminde sahip olmasının mümkün olmadığı torun sahibi olmak durumundan örnek vererek sürecin kendisine sağladığı avantajlardan bahsetmektedir. Bir diğer değindiği nokta ise yaşlanma sürecinin kendisine kazandırdığı perspektiftir. Bu sürecin hayatında veya gündelik yaşamında meydana gelen olayları değerlendirme biçimini etkilediğini belirtmektedir. K1 ise yaşlanma sürecinde yaşadığı kayıplar ve dezavantajlara karşı, elde ettiği yaşam tecrübesi sayesinde başa çıkma stratejileri geliştirdiğini bu nedenle yaşlanmayı tecrübe olarak nitelendirdiği görülmektedir.

Ben büyük kayıplar yaşadım. Önce iki çocuğumu sonra eşimi kaybettim. Büyük buhranlar yaşadım. Ama şimdi bana bir bakar mısın? Hep renkli giyinirim. Hep pozitif olmaya çalışırım. Tabii bu kolay olmuyor. Zor günleri atlatmam zaman aldı. Eşim öldükten sonra NLP eğitimlerine başladım. Öncesi kaygılarım vardı ama artık yok. Bu nedenle tecrübe. Yaşam tecrübesi diyorum (K1, 67 Üniversite).

E3 ise yaşlanma sürecinde K2 gibi fiziksel değişimlerin etkilerinden bahsederken K1 ve E5 gibi bu dönemin kendisine tecrübe kazandırdığını söylemektedir.

Yani vücut deforme oluyor. Tamamen bütün organlarımız biraz deformasyon oluyoruz yani. Eskisi gibi hırslı olmuyorsun. Yani bu benim elimdeki bu bana yetiyor diyebiliyorsun. Ben öyleyim şahsen. Elimdeki ile yetinmesini biliyorum. Ama içimdeki yaşam ışığı sönmüyor her gün yeni bir başlangıç gibi. Geçmişten bugüne gelen başka özelliklerim gelişiyor. Şu an mesela gel koşalım deseniz ben sizinle aynı kulvarda koşamam. Ama 6. his kuvvetleniyor. Ben şahsen 6. hissimi daha iyi kullanabiliyorum. Tecrübe diyelim (E3, 66 ilkokul).

E4' ün ise hayatın kesintisiz bir şekilde devam ettiğini ve içsel olarak kendini bir devinimin içinde hissettiğini bu nedenle de yaşlanma sürecini süreklilik olarak değerlendirdiğini görebilmekteyiz.

Ben içeriden dışarıya baktığım için her zaman uyuyup uyanmam dişında hep bir süreklilik var. Dolayısılla ben içeriden dışarı bakarak yaşlandım diye bir şey hissedemiyorum. Bilemiyorum. Bende bir tane hayat var o hayatın içinde uyanıyorum ve hareket ediyorum ve insanlarla konuşuyorum sohbet ediyorum tekrar yatıyorum ve devam ediyor hayat. Zaman içinde girdiğin çevreler değişiyor ama sen varsın onun içinde sen devam ediyorsun... (E4, 70 Y.Lisans).

E2'de yaşlanma sürecini hayata dokunmak hayatla bağlantı içinde olmak olarak tanımlamaktadır ve buradan hareketle bu sürecin devamlılık ve süreklilik içerdiğini belirtmektedir.

60 yaş, 70 yaş, 80 yaş bana göre yaş değil. Ne zaman ki hayatla bağların kopar, hayattan beklentilerin biter. Hayattan tat almamaya başlarsın o zaman yaşlanmışsındır (E2, 61 Üniversite).

Katılımcıların yaşlanmayla ilgili cevaplarına bakıldığında, yaşlanma süreçlerini yaşamları boyunca karşılaştıkları zorluklar, yaşadıkları kayıplar, elde ettikleri kazanımlar ve yaşam tecrübelerine atıf vererek tanımladıkları görülmüştür. Geçmişte elde ettikleri tecrübelerin şu ana ait yaşam deneyimlerine katkısından sıkça bahsettikleri de görülmektedir. Katılımcılar buna ek olarak yaşlanma sürecini fiziksel değişimler ve süreklilik temalarıyla değerlendirmişlerdir.

Görüşme yapılan bireylere ayrı bir soru olarak yaşlı kimdir veya yaşlı denildiğinde aklınıza ne gelmektedir gibi sorular sorulmamıştır. 
Ancak yapılan görüşmeler sonucunda bazı katılımcıların yaşlı ile ilgili olumsuz tutum ve yargılara sahip oldukları ancak kendilerini olumsuz anlamda yaşlı bir birey olmanın dışında tuttukları görülmektedir. Katılımcıların kendilerine dönük olumlu ve pozitif algılarını, yaşlılığa dair olumsuz tutum ve yargıları yeniden üreterek ifade ettikleri belirtilmeli. Burada aynı zamanda sınıfsal farkın yaş ayrımcılığını beslediğini de görmekteyiz. Kısacası katılımcılar bir yandan yaş ayrımcılığı yaparken bir yandan kendilerine dönük yaş algılarında olumlu ve pozitif tutum sergilemektedirler. Yani bu iki durum birbirini beslemektedir. Katılımcıların görüşlerinden bazıları şu şekildedir.

Yaşlı deyince ne bileyim işte köylerde sırtında ceketi başında şapkası elinde tespihi efendime söyleyeyim onlar geliyor. Ama ben herhalde öyle olmam yani. Kahve köşelerinde işsiz güçsüz kendine bir meşguliyet bulamayan tip ben asla böyle bir şeyi kabul etmiyorum (E5, 64 Üniversite).

Yaşlı deyince, hiçbir şey yapamaz, dişleri dökük, yürüyemez acınacak haldeki kişiler gibi düşünüyorum. Insanın kendini hissetmesine bağlı. Ben kendimi öyle hissetmiyorum (E7, 62 Lise).

Katılımcıların yanıtlarından oluşturulan temalara bakıldığında emeklilik dönemi ile ilgili sosyal güvence, gelir, köşe yastığı, toruna bakma, istediği kadar çalışma gibi kavramlar karşımıza çıkmaktadır.

Toplumda köşe yastığı, ilaç doktor eczane ve toruna bakma moduna giriyor insanlar. Pandemi öncesi daha doğrusu çalışma yaşamında saatlerim belliydi benim. Ama şimdi kurslar falan dolu zamanım oluyor emeklilikte. Zamanım çok. Köşe yastığı mantığı bana uymuyor zaten (K1, 67 Üniversite).

...emeklilik sadece benim bir iki kurumla çalıştığım birikmiş paraların artık yaş haddinden sen artık çalışma gençlere sira gelsin sen evde otur ben sana para vereyim dediği sosyal bir sistem. Onun dışında emekliliğin benim yaşamımı çok değiştirdiğini zannetmiyorum. Yani sonuçta kimin emekli olduğu kimin emekli olmadığı alnında damga ile belirtilmiyor. Genelde yaş olarak bakıldığında bu emeklidir bu değildir diye tahmin ediliyor. Yani biri çıkıp ben hayatımda hiç çalışmadım emekli değilim diyebilir değil mi (gülüyor) (E4, 70 Y.lisans).

Çok kişiler görüyorum yaşlı evine giderken parkta oturuyorlar. Bende bazen oturuyorum dinlenmek için. Diyorum ki ne yapıyorsunuz burada oturup sıkılmıyor musunuz? Sizin buraya yakın yaşlı evi açıldı gelin orada etkinliklere katılın diyorum. Yani insan istedi mi emekli olmaz (K7, 91 Üniversite).

Araştırmaya katılan bireylerin emeklilik dönemine ilişkin ifadelerine baktığımızda geçmiş yıllarda çalışıp biriktirdikleri ve bunun karşılığında devletin kendilerine sağladığı sosyal güvencenin çok daha ötesinde anlamlar ifade ettiğini görebilmekteyiz. Katılımcıların hepsi öncelikle "finans" bağlamında bir değerlendirme yapmıştır. Bu bakımdan emekliliği aslında finans kafesine hapsettikleri fakat kendilerini o kafesin dışında tuttukları görülmektedir. Bu görüşlere ek olarak, görüşme yapılan bireyler belli bir yaş eşiğini geçmiş olmalarına rağmen kendilerini gerek meslekleri gerek hobileri ve uğraşları etrafında geliştirmeye devam ettiklerini, boş zaman yönetimlerini yapabildikleri için resmi anlamda emekli olmalarına rağmen; gayri resmi olarak kendilerini emekli görmediklerini sıkça belirtmişlerdir.

Katılımcılar içinde bulundukları durumu karşılama tarzları akranlarına göre kendilerini konumlandırma biçimlerine yönelik sorulara şu şekilde cevap vermektedir. 


\section{senex • YAşLILIK ÇALIŞMALARI DERGİsi | JOURNAL OF AGING STUDieS}

Asla yaşlı olarak kabul etmem. Hatta arkadaşlarım bile der bu enerjiyi nereden alıyorsun diye. Bende fazla yemiyorum beni ağırlaştırmıyor derim. Enerjim devamlı yerindedir. Torunum bile diyor ki anneanne seni oksijen mi çarptı bu enerji nereden geliyor diyor (gülüyor) (K4, 64 Lise).

Katılımcının yanıtlarından kendini yaşlı olarak hissetmediği bunun sağlıklı bir yaşam tarzından kaynaklandığını belirtmektedir. K3' e baktığımızda benzer bir tutum içinde olduğunu görebilmekteyiz. Katılımcı bu durumu şu şekilde ifade etmektedir:

Yok hatta çılgın kabul ederim (gülüyor). Ben yaşımı çok seviyorum. Hiç de saklamıyorum. İşte herkes diyor ki çok genç görünüyorsun. Benim için hiç önemli değil. Ben mesela şu an genç yaşlarıma hiç dönmek istemiyorum. Bu yaşın pek çok güzellikleri var. Mesela yaşanmışlıklar var. Hayat tecrübeleri var. Insanları daha çok gözlemliyorum daha kolay seçebiliyorum iyi doğruyu güzeli. O yüzden bu yaşımı seviyorum hiç de gocunmuyorum (K3, 60 Lise).

Katılımcının ifadelerinden yaşlılık ve yaşlanmaya karşı olumlu bir tutum içinde olduğu söylenebilir. Birey içinde bulunduğu durumu kabullenmiş ve bu durum ile barışık bir yaşam sürdürme eğilimindedir. Iç̧inde bulunduğu dönemi, yaşam boyu kazandığı deneyimlerin meyvesini aldığı bir dönem olarak değerlendirdiğini söylemek doğru olacaktır. E4 ise kendini sayılardan bağımsız olarak hayatını bir bütün olarak değerlendirdiğini ve bu değerlendirmenin kendisini içsel olarak rahat hissettirdiğini belirtmektedir. Katılımcı kendi içsel durumunu şu sözlerle ifade etmektedir.

Yani yaş sayıylaysa tabi ki bundan kaçınılmıyor ama onun dışında hayır. Yani kronolojik olarak 2000 yıl önce ilan edilmiş bir takvime göre 365 günde bir yıl diye bir isim koymuşlar ama onun dışında hayat bir süreklilik içeriyor benim için. Ben içsel olarak kendimi iyi ve rahat hissediyorum. Çevremi de rahat ettirmeye çalışıyorum (E4, 70 Y.Lisans).

Diğer taraftan E1'in ifadelerine baktığımızda klasik anlamda yaş ile ilgili tanımların öğrenilmiş tanımlar olduğu ve kişi ön yargılarından bağımsız olduğu zaman kendini yaşla tanımlamanın dışında içsel durumu ve hislerine yönelik davranışlar sergileyebileceği anlaşılmaktadır.

Yaşlılık hissine sahip değilim. Her ne kadar yaş ilerliyor olsa da yaş ile gelen fiziksel belki ufak tefek sınırlamalar dışında yaşlılık hissi taşımıyorum. Akranlarıma göre daha yaş ile tanımlı olmayan bir aktivite ve ruh hali içerisindeyim. Yani yaşın bana getirdiği bir sınır yok. Yapmak istediklerim ve istemediklerimle ilgili. Yaşa hesaba katarak yapmak istediğim ve istemediğim şeyler yok yani yaş gündemimde değil (E1, 60 Üniversite).

$\mathrm{K} 1$ 'in ise ileri yaş ile ilgili ifadelerini fiziksel gerilemelerle tanımladığı görülmektedir. Kendisini aktif bir insan olarak tanımlayan katıımcı bu aktifliğin akranlarından farklı olarak kendisine bedensel, zihinsel ve ruhsal dinçlik kattığını belirtmektedir. Katılımcı bu durumu şu şekilde ifade etmektedir:

Hiç görmedim. Sadece yaşımı sorduklarında ve söylediğimde haa ben büyümüşüm diyorum. Yaşlanmışım demiyorum ama o da sayıdan dolayı. Çünkü arkadaşlarım hep şunu diyorlar: Ay benim annem filanca tanıdığım 55 yaşını geçti sendeki aktivitenin yarısı onlarda yok... biraz da bedensel, ruhsal ve zihinsel dinçlik diyelim $\operatorname{artık}(K 1,67$ Üniversite).

Diğer bir katılımcı olan K2'nin ise K1' e benzer bir şekilde yaş ile ilgili ifadelerini fiziksel gerileme durumu ve buna ek olarak gençlik ile kıyas yaparak tanımladığı görülmektedir. 
Yoo hissetmiyorum. Ne zaman hissediyorum biliyor musun mesela bankada falan senin gibi genç bir memur gördügüm de o zaman biz yaşlandık mı modunda oluyorum... yaşlandığımız demiyorum yaş aldığımız diyorum. Fiziksel olarak bir his bu zihinsel veya duygusal değil (K2, 65 Üniversite).

K8 katılımcısı ise kendi içsel durumunu diğer katılımcılardan farklı olarak evli olmamasına dayandırmaktadır.

Kendimi yaşlı biri olarak görmüyorum. Akranlarımla kıyasladığımda kendimi daha özgür hissediyorum. Benim genel kültürüm fazla olduğu için ben hem yurt içinde hem yurt dışında çok gezdim. Şimdi benim arkadaşlarım hep evli barklı olmuşlar. Ben yalnız yaşadığım için daha özgürüm. Daha farklı alternatifler yaşadım. Onlar eşleri ile yaşadıkları için mecburen onlarla birlikte hareket ediyorlar (K8, 67 Lise).

Katılımcıların sorulara verdikleri yanıtlardan kendi yaşlarına ve yaşam pratiklerine karşı olumlu bir tutum içinde olduklarını görmekteyiz. Genel olarak tutumları, akranlarına kıyasla daha iyi bir yaşlılık dönemi geçirdikleri yönündedir. Yaşlı olmayı ve yaşlılık durumunun fiziksel bir durum olduğunu zihinsel ve ruhsal olarak ise hayatlarının bir süreklilik içerdiğini belirtmektedirler. Bu süreklilik duygusu ve davranışsal tutumları toplumun geneline yayılmış bir şekilde hazır kodların kullanılması ile değil, tam tersine bu hazır kodların işaret ettiği kabulleri ters yüz edercesine işlemekte olduğu görülmüştür. Katılımcıların kendilerini genel yaşlı kategorisinde görmediklerini, genel kanıda yer etmiş yaşlı tipolojisinin anlam, eylem ve kültürel boyutlarını görmezden gelerek kendilerine yeni bir sosyalleşme alanı açmaya çalıştıklarını görmekteyiz. Zira bu tutumla perennial birey olma haline örneklik teşkil ettiklerini rahatlıkla ifade edebiliriz. Yaşlılık evresinin bir tersine durum olarak yeni fırsatları barındıran, heyecan uyandıran, eksik bırakılanın tamamlandığı, özgürlüğün yeni bir boyut kazandığı vb. gibi yaşlıık genel terminolojisine uymayan kendine özgü bir yaşlı tipolojisini ürettiği görülmektedir. Yaşlılığın reddi olarak da ifade edilebilecek bu durum yer yer bir hissiyatın, yer yer ise bir davranışın ana bileşeni olarak kendini göstermektedir. Bir sonraki başlıkta bu durum daha da detaylandırılacaktır.

\section{Hislerin Bedene Yansımaları}

Katılımcıların kendilerine ve yaşlılığa yönelik sorulan sorulara verdikleri yanıtlara bakıldığında kendini "yaşlı hissetmemek" temasının ön plana çıktığını görmekteyiz. Yaşlı hissetmeme hali, zihinsel olduğu kadar fiziksel bir temele de sahiptir. Zihinsel ve fiziksel olanın bu eş zamanlılığını, hislerin bedene yansımasından hareketle görebiliriz. Yapılan gözlemlerde yaşsız yaşlı toplumsal tipini oluşturan bireylerin akranlarına kıyasla nispeten daha dinç/ diri ve fiziksel açıdan kendine yetebilen bireyler oldukları görülmektedir. Bu durum katılımcıların yaşam seyri boyunca edindiği düzenli spor yapma alışkanlıklarının bir sonucu olarak değerlendirilebilir. Bu alışkanlık ileri yaşlarda bireylere kümülatif avantajlardan birini de sağlamaktadır. Söz gelimi, yaşlı bireyler, orta yaş dönemindeki fiziksel aktivitelerini gerçekleştirmeye devam ettiklerini belirtmektedirler. E2 katılımcısı bu durumu şu şekilde ifade etmektedir:

35 yaşında 45 yaşında yaptığım etkinlikleri fiziksel anlamdaki etkinlikleri mutlaka farklı yöntemlerle yapmaya başladım...Her gün düzenli olarak yürüyüşüme devam ediyorum (E2, 61Üniversite).

E2 spor yapma alışkanlıklarını orta yaşlarda kazandığını ve ileri yaşlarda bu alışkanlığını farklı şekillerde de olsa devam ettirdiğini belirtmiştir. K4 katılımcısı ise; 
Ben çobanlık yaptım dana güttüm dana otlattım. Dana otlatırken dağlara gider ormanlarda yürürdüm. O zamanlardan beri dağlara giderim, ormanlarda yürümeyi doğayı çok severim. Hatta 55 yaşında kendi çabalarımla yüzme öğrendim (K4, 64 Lise).

K4'ün ise diğer katılımcılardan farklı bir yaşam seyrine sahip olduğu görülmektedir. Fiziksel aktivite alışkanlıklarını da farklı şekillerde edinmiştir. Katılımcı küçük yaşlarda fiziksel olarak aktif bir dönem geçirmiş ve ileri yaşlarda bu aktiviteyi devam ettirmiştir.

Katılımcıların yine dış görünümlerine bakıldığında, kişisel bakımlarına özen gösterdikleri görülmektedir. Yapılan saha gözlemlerinde erkek katılımcılardan E1, E2, E4 ve E7 'nin ağırlıklı olarak spor bir giyim tarzını, E3, E5 ve E6'nın ise iş yaşamındaki alışkanlıklarını devam ettirdikleri ve daha resmi bir giyim tarzını tercih ettikleri görülmektedir. Diğer katılımcılardan farklı olarak özelikle üst sınıftan olan E2'nin marka giyime önem verdiği, orta sınıftan olan E3 ise markadan ziyade kalite ve kıyafetin görünüşüne önem verdiği görülmektedir. E3 bu durumu şu şekilde ifade etmektedir;

Kişi vardır gider 500 tl'lik elbise alır o elbise o kişinin fiziği onu taşır. Ama kişi vardır 5000 tı'lik elbise alır. O kişinin fiziği onu taşıyamaz. Bende gençler sağ olsun beni motive edici şeyler söylerler ... abi fitsin diye. Işte gidip çok lüks yerden değil yerine gidip pazardan da gömlek ve pantolon alıp giyebilirim. Önemli olan giyimin kalitesidir. Onu taşıyabilmek çok önemlidir (E3, 66 ilkokul).

Erkek katılımcıların genel olarak spor ve resmi giyim olarak iki tarzda giyinmeye özen gösterdikleri görülmektedir. Katılımcıların giyimlerinde etkili olan faktörler geçmiş yaşam alışkanlıkları, sınıf ve kişisel tercihlerdir.

Kadın katılımcıların ise giyim tarzlarının içinde bulundukları sınıfa ve kişisel tercihlere göre değişkenlik gösterdiğini söylemek mümkündür. Orta sınıfta bulunan kadınlar daha çok sportif bir giyim tarzı tercih ederken, orta üstü ve üst sınıfta bulunan kadınların sade ve şık giyim tercih ettikleri görülmektedir. Orta sınıftan olan K3:

Daha çok rahat edebileceğim şeyleri tercih ediyorum. Moda sana yakışandır derler ya bence öyle. Hani çok böyle farklı şeyler giyinmeyi sevmiyorum. Normal sıradan ve rahat şeyler giyiniyorum. Ama zarif şeyler giyinmeye özen gösteriyorum (K3, 60 Lise).

Orta üstü sınıftan olan K7 saçlarının hep fönlü olduğunu, renkli ojeler, renkli şapkalar ve ceketler giymeyi sevdiğini söylemiş ve giyim tarzını kokoş olarak belirtmiştir. Ayrıca şık giyinmeyi sevdiğini vurgulamıştır. Üst sınıftan olan K8 ise her zaman temiz ve şık giyinmeyi tercih ettiğini belirtmiştir. Oysa yaşlının davranışını belirli kalıp yargılarla sınırlayan ve bu kalıplaşmış yargıların yarattığı etki ile kıyafet tercihlerindeki geleneksel giyim tarzı tercihi giderek ortadan kalkmaktadır. Kırmızı pantolonuyla bir yaşlı erkeğin konser izlemeye gitmesi veya yeni peruğuyla ve makyajıyla yaşlı bir kadının vitrinler önünde arzı endam etmesi giderek normalin sınırları içine çekilmektedir.

Günümüz bireyinin kendini mevcut konfor şartlarında yeni alışkanlıklarla donatmasına paralel olarak, yaşlılık sürecine aktarılacak böylesi yaşama kodlarının yaşlılarda da oldukça sık tezahür edeceğini düşünebiliriz. Kaldı ki bu yeni insanın yaşam seyrini aktif bir şekilde uzatması olarak da görülebilir. Yanı sıra yaşııı̆ı̆ gelişen toplumsal etkinlik ve hizmetlerle yeni bir sosyalleşme evresine tekabül ettiği de bir başka realitedir. Artık yaşamın her evresinde olduğu gibi kapitalist kültürün insanlara sunduğu alternatifler içinde yaşlılara yönelik ilgi çekici sembolik bir evreni tasarladığı görülmektedir. Yaşlı bakım hizmetlerinin "özel" uygulamaları gibi, 
yaşlıların tüketim evrenine dönük pazarın sundukları, sağlıklı yaşam için önerilen yeni alışkanlıkların toplumsal mekanizmalar tarafından desteklenerek çoğaltılması, eğlence, seyahat, sınırları ortadan kaldıran aktiviteler, "yeni" kavramı etrafında sunulan hizmetler, entelektüel çaba vb. daha pek çok başlık yeni yaşlı birey tipolojisini daha bir görünür kılarken, geleneksel yaşlı tipolojisinin de toplumsal görünümlerinin tamamen ortadan kalkmasa da giderek azalacağı öngörüsünü yakınlaştırmaktadır.

\section{Tartışma}

Görüşme yapılan bireylerin sorulara verdiği cevaplardan yola çıkarak bir sosyal harita oluşturulmuştur. Harita "yaşsız yaşı" toplumsal tipini sosyal dünyada görünür kılan unsurlarve bu unsurların birbiriyle olan ilişkisini anlayabilmemize yardımcı olacaktır. Sosyal harita, çalışmada anlatılanların okuyucunun aklındaki soyut temsillerin daha somut bir duruma gelebilmesi açısından önem arz etmektedir. Toplumsal uzam, betimlediği biçimi ile bir harita gibi, kuş bakışı bir görüş ve sıradan eyleyicilerin toplumsal dünyaya dair sahip oldukları görüşleri dayandırdıkları noktaların tümü üzerine bir bakış açısı sağlayan, özgül bir çalışmanın inşası için üretilmiş soyut temsilidir (Bourdieu, 2015; 253). Bu çalışmada da yaşsız yaşlı toplumsal tipini oluşturan bireylerin toplumsal uzamdaki yerini anlayabilmek için katılımcılarla yapılan bireysel görüşmeler neticesinde oluşturulan yaşsız sosyal harita tartışılacaktır. Daha sonra tartışma detaylandırılacaktır.

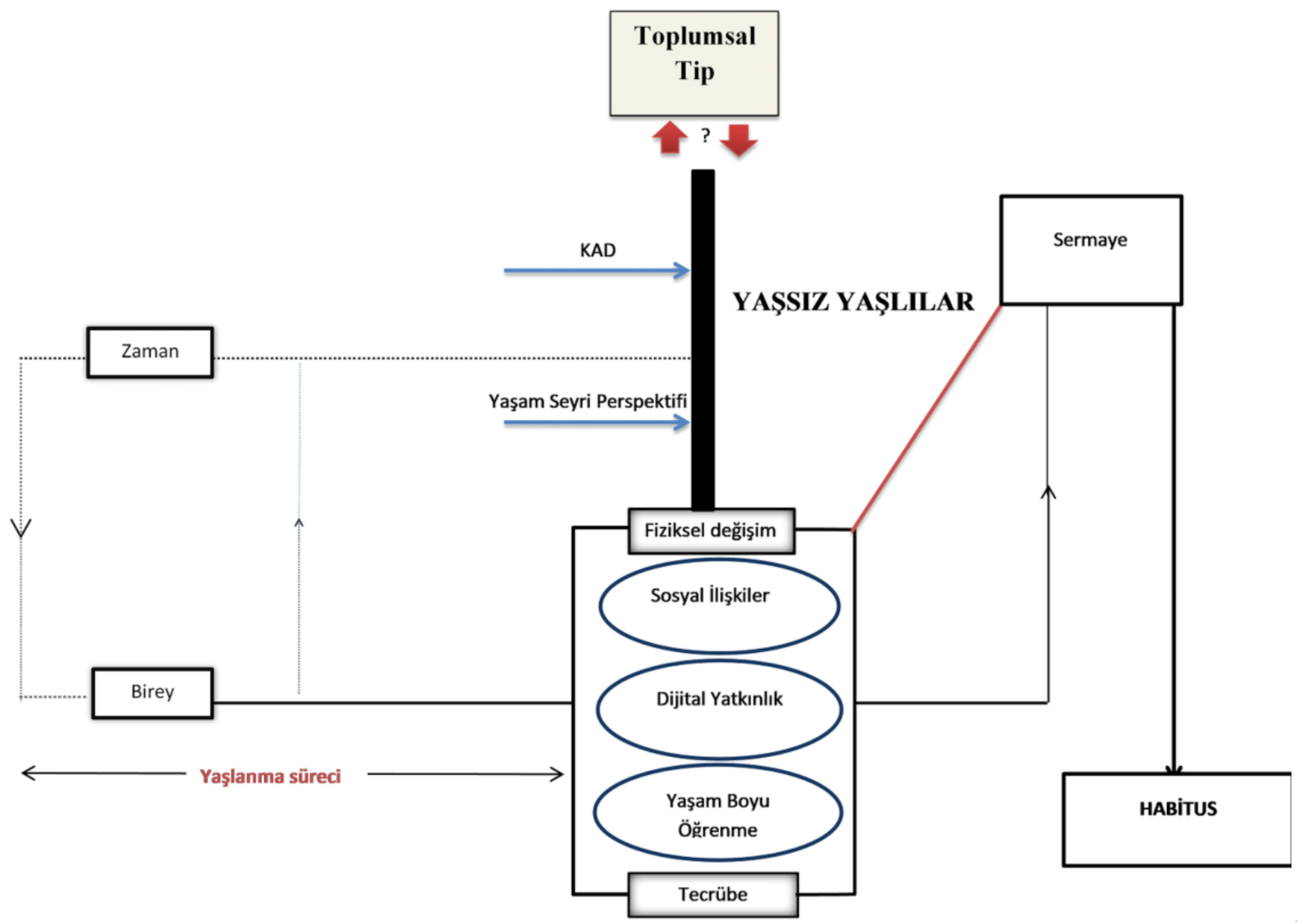


Oluşturulan sosyal haritaya bakıldığında karşımıza yaşsız yaşlı sosyal tipinin belirleyenleri çıkmaktadır. Her birey zamanla yaşlanır. Yaşlandıkça fiziksel değişimler yaşarken aynı zamanda tecrübe edinmeye devam eder. Yaşlanma süreci devam ederken birey yaşanan büyük toplumsal gelişmelerden ve kendisi için önemli olan geçiş dönemlerinde hayatını olumlu veya olumsuz etkileyebilecek olaylara maruz kalabilmektedir. Bireyin maruz kaldığı olumlu veya olumsuz olaylar yaşamının ileriki dönemleri için birikimler oluşturmaktadır. Fiziksel değişim ve tecrübe paralelinde devam eden bu süreçte birey, sosyal ilişkilerini ve dijital yatkınlığını geliştirirken; yaşam boyu öğrenme aktivitelerini de sürdürür. Böylece var olan kültürel, ve sosyal sermayesinin sınırları genişler ve var olan ekonomik sermayesinin de desteği ile aslında toplumda benzer özellikteki bireylerle daha çok bir arada bulunarak kendi ortamlarını oluştururlar veya var olan ortamlara dahil olurlar. Bireylerin ağırlıklı olarak lise ve üniversite mezunu olması, ekonomik sermayeleri sayesinde başta teknolojik imkanlar olmak üzere pek çok imkana erişim fırsatlarının olması ve sosyal sermayelerinin genişliği böyle bir toplumsal tipin oluşmasına imkan sağlamaktadır. Bireylerin yaşlanma süreçlerini, KAD (Kümülatif Avantajlar/ Dezavantajlar Teorisi) ve yaşam seyri perspektifi ile değerlendirdiğimizde yaşsız yaşıları bir toplumsal tip olarak ortaya koyabilmekteyiz. Bireylerin maruz kaldıkları birtakım unsurlar aslında onların yaşam tarzlarını da belirlemektedir. Habitus ve sermaye kavramı ise yaşam seyri perspektifi ve KAD teorisinin toplumsal tipi açıklamada eksik kaldığı yerleri tamamlamaktadır. Bireylerin yaşam boyu elde edilen avantajların ve dezavantajların bedene nasıl yansıdığını habitus kavramı ile açıklayabilmekteyiz.

Yaşsız yaşlı tipinin toplumsal uzamdaki belirleyenlerinin yaşam boyu öğrenme, dijital yatkınlık, sosyal ilişkiler ve yaşla ilgili kavramlara yönelik algılar olduğunu söylemek mümkündür. Katılımcıların sosyal medya ve internet ile ilgili verdikleri cevaplara bakıldığında, sosyal medya ve interneti işlevine uygun kullanabilen, arkadaşları ve akrabaları ile whatsapp üzerinden haberleşebilen, katılmayı planladıkları etkinlikleri facebook üzerinden takip eden, merak ettikleri konular üzerinden araştırma yaparken arama motorlarını aktif kullanabilen, haberleri kağıt gazete almak yerine elektronik ortamdan okuyabilen ve banka işlemleri gibi resmi işlemlerini akıllı telefonlarında gerçekleştirebilen yaşlı bireylerin oluşturduğu bir toplumsal tip karşımıza çıkmaktadır. ileri yaşlardaki bireylerin dijital teknolojileri kullanımlarına yönelik elde ettiğimiz veriler literatürdeki diğer bazı çalışmalarla karşılaştırıldığında farklı çıktılar elde eden araştırmacıların yanında benzer çıktılar elde eden araştırmacılar da karşımıza çıkmaktadır. Bunlardan biri Canatan (2014) tarafindan yazılan "Eski Toprak" toplumsal tipidir. Bu yazıda, EskiToprak'ın dünyayaaçılan penceresi olarak televizyon ön plana çıkmaktadır. Yaşlı bireyleri cep telefonu ve internetten uzak bireyler olarak tipleştirmektedir. Fakat perennial toplumsal tipi, çağın gereklerine ayak uydurabilen ve hayatın pek çok alanında internet, sosyal medya ve bunları kullanım aracı olarak akıllı telefon ve bilgisayar kullanmaktadır. Yani perennial bireyin dünyaya açılan kapısını televizyondan ziyade bu mecralar oluşturmaktadır. Daha güncel çalışmalara bakıldığında ise Uysal (2020) gerçekleştirdiği çalışmasında ileri yaşlarda dijital teknoloji ile tanışan bireyleri; kaçınanlar, zoraki benimseyenler ve hevesliler olarak 3 grupta ele almıştır. Hevesliler grubu içerisine giren bireyler e- posta, facebook gibi uygulamaları günlük yaşamları içinde aktif olarak kullanırlar ve bu grupta yer alan yaşlılar teknolojinin değerini görüp bunu kullanmak için de heveslidirler. Bu bakımdan değerlendirildiğinde yaşsız yaşlıların dijital teknolojilere yönelik bakış açıları ve 
kullanımlarını destekler niteliktedir.

Yaşlanma ve yaşamın ilerleyen evrelerini değerlendirirken sadece olumsuz deneyimlere tekabül eden olgular olarak algılamak bize dar bir bakış açısı sunar (Wright, 2020). Bu bakış açısını genişletebilmek adına bireylerin olumsuz deneyimlerini göz ardı etmeden onların olumlu deneyimlerini de çerçevenin içine katabilmek daha kapsayıcı bir bakış açısı sunabilmektedir. Ferraro \& Shippee (2009) yaşamın çocukluk dönemi gibi erken dönemlerde maruz kalınan avantaj ve dezavantajların yaşamın ilerleyen evrelerindeki etkilerini incelemişlerdir. Elde ettikleri sonuçlar bu avantaj/dezavantajlardan kaynaklı birikimlerin yaşamın ilerleyen dönemlerinde eşitsiz bir yaşlanmaya sebep olabileceği yönünde olmuştur. Nitekim araştırma kapsamında perennial bireylerin yaşlanmaya ilişkin algılarına baktığımızda da yaşam boyunca karşılaştıkları zorluklar, yaşadıkları kayıplar, elde ettikleri kazanımlar ve yaşam tecrübelerini birikime vurgu yaparak değerlendirdikleri görülmektedir. Geçmişten günümüze biriktirdiklerinin onların şu anki yaşama deneyimlerini şekillendirdiğini söyleyebiliriz. Bu birikimi, ekonomi gelir, kültürel birikim, sosyal ilişkilerdeki zenginlik olarak tanımlayabiliriz.

Baum \& Boxley (1983) yaş tanımlama üzerine yaptıkları bir çalışmada ise kronolojik yaş ile bireylerin kendi yaş algıları arasındaki tutarsızlığı vurgulamıştır. Kişilerin yaşlı etiketinden dolayı yaşlarını inkâr ettiklerini bunun sebebininse bireylerin fiziksel, psikolojik ve sosyal açıdan iyilik hali içinde olmalarından kaynaklandığını belirtmektedir. Perennial bireylerin yaşlılık dönemine yönelik sorulara verdikleri yanıtlardan yola çıkarak, yaşamın bu dönemini alternatif bir yaşam tecrübesi olarak değerlendirdikleri söylenebilir. Çünkü yaşsız yaşlıların bu dönemin, fiziksel değişimlerin ötesinde bir süreklilik arz ettiğini ve süreklilik durumunun sonucunda kendilerinin yaşlılık hissine sahip olmadıklarını belirtmişlerdir.

Katıımcıların yaşlı bireylere yönelik ifadeleri oldukça ilgi çekicidir. Çünkü katılımcılar yaşlı bir bireyi olumsuz tanımlamalarla betimlemişlerdir. Fakat kendilerini bu olumsuz tanımlama ve betimlemelerin dışında tutmaktadırlar. Katılımcıların emeklilik dönemini dar bir çerçevede yani sosyal güvence ve ekonomi bağlamında değerlendirdikleri görülmektedir. Bu iki bağlam dışında bu dönemin onlar için pek bir anlam ifade etmediği söylenebilir. Perennial bireyler emeklilik dönemini iş yaşamından veya hayattan geri çekilme olarak değil aksine toplumsal hayata katılımın daha da çeşitlendiği ve daha çok nüfus ettikleri bir dönem olarak tanımlamaktadırlar.

Yaşsız yaşlılarda medeni durumun önemli bir sosyal sermaye potansiyeli olarak sosyal ilişki ağlarında ön plana çıktığı görülmektedir. Öyle ki sosyal sermaye ağları yaşsız yaşlıların sahip olduğu yaşam standartlarını belirleyen önemli bir bileşen olarak karşımıza çıkmaktadır. Özellikle medeni duruma bağlı olarak yaşsız yaşlı bireylerin kuruduğu ilişkiler, dahil oldukları etkinlikler, sosyalleşme imkanlarının kullanımı, mekân tercihleri, kültürel etkinliklerde yer alma vb. gibi daha pek çok sosyal etkileşim pratikleri değişmektedir. Evli ve geniş bir aileye sahip yaşsız yaşlılar daha çok aile içi bir sosyalleşmeyi tercih ederken; bekar olan, yalnız yaşayan perennial bireyler yaşlı evleri, tazelenme üniversitesi, meslek odaları vb. mekanlarda yani aile dışı bir sosyalliği tercih etmektedirler. Aynı zamanda bireylerin kurdukları ilişkilerde seçici davrandıkları görülmektedir. Bireyler özellikle yeni edindikleri arkadaşlıklarında kendileri ile uyumlu ve hayata pozitif bakan insanlarla ilişki kurmaktan hoşlandıklarını belirtmişlerdir. Perennial bireylerin sosyal ilişkilerine genel olarak baktığımızda aslında sosyal birikimlerinin ön plana çıktığını görebilmekteyiz. Perennial bireylerin yeni arkadaşlıklar edinmek gibi eylemleri 
zorlanmadan

gerçekleştirebildikleri

görülmektedir. Sosyal sermaye teorisinin özeti mahiyetindeki "ilişkiler önemlidir" (Field, 2006) cümlesi ile anlam kazanan toplumsal ilişkilerin yaşsız yaşlı bireyler için oldukça önemli bir potansiyele işaret ettiği görülmektedir. Yaşsız yaşlıların dâhil olduğu sosyal ağlarda kurdukları ilişkilerle bir sosyal sermaye potansiyeline sahip oldukları böylece yaşadıkları sorunların giderilmesi, hedeflerin gerçekleştirilmesi, sosyal benliğin canlı tutulması, etkileşim ve sosyal ilişkilerin sürdürülmesi vb. (Aydemir, 2011) ihtiyaç duyulan konularda canlı bir sosyal dünya inşa edebildikleri anlaşılmaktadır. Genel olarak yaşlı bireylerin hayat akışında sosyal ağlar ve ilişkilerin oldukça önemli bir yeri olduğu açıktır. Zira yaşlı birey için hayatın en zor kısmında yalnızlık gibi korku unsuru olabilecek bir gelecek tasarımı veya gerçeklik tehditleri içermektedir. Yaşlı bireylerin içine düştükleri karamsarlık, korku ve duygusal bunalımların yalnızlık ile ilgili olduğu, sosyal etkileşim ve ilişki potansiyeli yüksek olan bireylerin ise ileri yaşlanmanın olası olumsuz etkilerinden daha fazla korunabildiklerini düşünmek mümkündür. Perenniallerde de karşımıza çıkan güçlü sosyal ağlar üretebilen ve bunları sürdürebilen bireyler olduklarıdır. Hatta teknoloji ve sosyal medya kullanımı konusundaki becerilerinin belli bir kısmı bu ihtiyacın bir sonucu olarak tezahür etmektedir. Perennial bireylerdeki başat unsur olarak karşımıza çıkan dahil oldukları sosyal ağları etkin bir şekilde kullanabilme becerisi ve bu ağlar içinde kendi üretkenliklerini gösterebilme ve geliştirebilme imkânı olarak tespit edilmiştir.

\section{Sonuç}

Perennial bireyler özelinde gerçekleştirilen bu çalışma yaşlılık araştırmaları bağlamında bir ilki barındırmaktadır. ilk defa perennial birey üzerine bir tipoloji çalışması gerçekleştirilmiş, yaşlılık ve yaşlılar bir sosyal sorunun parçası olarak değil, bir sosyal realitenin aktörü olarak ele alınmıştır. Dolayısıyla bu çalışmanın ana ekseni yaşlılık etrafında geliştirilen bir sosyal sorun söylemini ispat etmek ve geçersiz kılmak değildir. Yahut yaşlılığa ilişkin genel düzeyde bir perspektif geliştirmek değildir. Bu çalışmanın amacı özel bir yaşlılık düzlemi olan perennialleri yani yaşsız yaşlıları gündeme taşımak ve giderek artan bir realite içinde onların varlığına ilişkin bir ilk tespiti Türkiye özelinde gerçekleştirmektir. Konunun önemi ilerleyen zamanlarda artacağı varsayılan perennial yahut yaşının çok ötesinde bir yaşam alanı inşa eden bu bireylerin bir kuşağın yaşlılık haline dönüşeceğidir. Geleneksel veya "eski toprak" tanımlaması ile anlaşılan ve üzerine incelemeler yapılan mevcut ve önceki yaşlı tipolojisinin giderek dönüşeceği ve yeni gelen neslin yaşam alışkanlıklarına bağlı olarak yeni bir yaşlanma deneyimini üreteceği kolaylıkla görülebilir. Gençlik ve olgunluk evresinde modern yaşam alışkanlıkları ve tüketim pratiklerine sahip bireylerin yaşlılık evresinde bu alışkanlıkları bir kenara bırakacağı ve bir anda ölüme hazırlanan veya pesimist bir dünyaya dahil olan bireylere dönüşeceğini beklemek mümkün görünmemektedir. Tersine benzer standartlarda bir hayatın ve hatta daha renkli ve çeşitlilik içeren ancak yaşama arzusu ve hevesiyle kendini diri tutmak isteyecek bireylerin yeni yaşlı tipolojisinin bir parçası olacağı söylenebilir. Batıda benzerleri üzerine inşa edilen yaşlı yaşam tarzı ve kültürel tüketim pratiklerinin hızla ülkemizde de görüleceğini bir ön kestirim olarak ifade edilebilir. Zira değişen yaşlılık algısından ziyade ortalama bireyin hayat tarzında kendini gösteren alışkanlıklar ve pratiklerle kendini dayatan bir tercihler skalasının dikkate alınacağıdır. Yaşlı ama nasıl? Sorusunu henüz başındayken soran bu tezin amacı "yaşsız ama yaşlı" şeklinde cevabını bulan bir toplumsal karakterin incelenmesi ile son bulmaktadır. 


\section{Kaynakça}

Achenbaum, W.A. (2013). " Pass As Prologue: Toward A Global History of Ageing." içinde Dannefer, D.\& Phillipson, C. (2013). The Sage Handbook of Social Gerontology. London: Sage.

Arun, Ö. (2018). Arayışlar: Türkiye'nin Yaşlanma Serüveni. Ö. Arun içinde, Yaşlanmayı Aşmak (s. 7-20). Ankara: Phoenix.

Arun, Ö. (2018). Yaşlılık: 21. Yüzyılın Türkiye'ye Sunduğu Armağan. Ö. Arun içinde, Yaşlanmayı Aşmak (s. 169-179). Ankara: Phoenix.

Aydemir, M. A., (2011). Sosyal Sermaye: Topluluk Duygusu ve Sosyal Sermaye Araştırması, Konya: Çizgi Kitapevi.

Aydemir, M. A. (2016). "Sosyal Alanın Tipleştirilmesi: Toplumsal Tipler" içinde Toplumsal Tipler, Ed.M.Ali Aydemir, . İstanbul: Açılım Kitap.

Baum,S.K., \& Boxley, R. L. (1983). Age identification in the elderly. The Gerontologist, 23(5), 532-537.

Bourdieu, P. (1979). Ayrım: beğeni yargısının toplumsal eleştirisi (D. Fırat\& G. Berkkurt. Çev.) Ankara: Heretik.

Carney, J. (Senarist), Carney, J (Yönetmen). (2019). The Race Grows Sweeter Near Its Final Lap [Televizyon dizisi bölümü]. Hoffman, T (Baş yapımcı), Modern Love içinde. New York. Amazon Prime Video.

Canatan, A. (2014). Eski Toprak. Sosyoloji Divanı, 37.

Dannefer, D. (2003). Cumulative advantage/ disadvantage and the life course: Cross fertilizing age and social science theory. The Journals of Gerontology: Social Sciences, 58(6), 327-337.
Duben, A. (2018). Türkiye ve Avrupa'da Nüfus Yaşlanması, Aile, Piyasa ve Devlet. A. Duben içinde, Yaşlanma ve Yaşlılık: Disiplinlerarası Bakış Açıları (s. 67- 76). İstanbul: Bilgi Üniversitesi Yayınları.

Ferraro, K. F., \& Shippee, T. P. (2009). Aging and cumulative inequality: How does inequality get under the skin?. The Gerontologist, 49(3), 333-343.

Field, J. (2006). Sosyal sermaye. (B. Bilgen, B. Şen, Çev.) Bilgi Illetişim Grubu Yayıncılık: istanbul.

Holman, D., \& Walker, A. (2020). Understanding unequal ageing: towards a synthesis of intersectionality and life course analyses. European Journal of Ageing, 1-17.

Kanbir, F. (2020). Türkiye'de yaşlılara yönelik toplumsal algılar ve politikalardaki değişim. Konya: Çizgi.

Morgen, L. A., \& Kunkel, S. R. (2016). Aging, Society, and the life course. New York: Springer Publishing Company.

Ok, B. (2014). İhtiyar. Sosyoloji Divanı, 195.

Palabıyık, A. (2011). Pierre bourdieu sosyolojisinde "habitus", "sermaye" ve "alan" üzerine. Liberal düşünce dergisi. 61. 121-141.

Stowe, J. D., \& Cooney, T. M. (2015). Examining Rowe and Kahn's concept of successful aging: Importance of taking a life course perspective. The Gerontologist, 55(1), 43-50.

Tunçer, M. (2020). Kriz döneminde yaşçılık: yeni mücadele alanları. Cogito, 98, 144-152. Wright, G.C. (2020). Yaşlanma, yaşlılık ve yaşlılar: Kavramsal tartışmalar, toplumsal 
senex • YAşLilik ÇAlişmalari Dergísí | JOURnal of Aging Studies

algılar ve yaşlının sosyal statüsü. Cogito, 98, Yıldız, A. (2014). Hayata Yaşlı Bakış: Ömür 120-144.

Dediğin Programı. Sosyoloji Divanı, 16 